\title{
Influence of Combined Application of Cattle Dung and NPK Fertilizer on Soil Physico-Chemical Properties, Growth, Nutrient Uptake and Yield of Fluted Pumpkin (Telfairia occidentalis) in Anyigba, Kogi State, Nigeria
}

Frank O. O*, Paul O. J, Amhakhian S. O

Department of Soil and Environmental Management, Faculty of Agriculture, Kogi State University, Anyigba, P.M.B. 1008, Anyigba, Kogi State, Nigeria

\section{*Corresponding Author}

Frank Ojomah Ojochegbe

\section{Article History}

Received: 27.07.2019

Accepted: 06.08.2019

Published: 14.01.2020

\begin{abstract}
This study evaluated the influence of combined application of cattle dung and NPK fertilizer (NPK 15 -15 -15) on soil physicochemical properties, growth, nutrient uptake and yield of fluted pumpkin (Telfairia occidentalis) during the dry season of 2015. The pot experiment was conducted at Faculty of Agriculture Complex, Kogi State University, Anyigba in a Completely Randomized Design (CRD) with seven treatments and four replicates. The treatments were $250 \mathrm{~kg} / \mathrm{ha}$ NPK fertilizer, $2 \mathrm{t} / \mathrm{ha}$ cow dung, $2 \mathrm{t} / \mathrm{ha}$ cow dung $+250 \mathrm{~kg} / \mathrm{ha}$ NPK fertilizer, $3 \mathrm{t} / \mathrm{ha}$ cow dung $+300 \mathrm{~kg}$ NPK fertilizer, $4 \mathrm{t} / \mathrm{ha}$ cow dung $+350 \mathrm{~kg}$ NPK fertilizer, $5 \mathrm{t} / \mathrm{ha}$ cow dung $+400 \mathrm{~kg}$ NPK fertilizer and a control. The following growth and yield parameters were measured; average number of leaves, branches, stem girth and internode length. Results from this study showed that combined application of cow dung and NPK fertilizer significantly $(\mathrm{P}<0.05)$ increased organic carbon, available $\mathrm{P}$, soil $\mathrm{pH}$, total nitrogen, exchangeable bases and Effective Cation Exchange Capacity compared to the control. The amendments did not significantly influence soil physical properties. Uptake of $\mathrm{N}$, $\mathrm{P}, \mathrm{K}, \mathrm{Ca}$ and $\mathrm{Mg}$ were higher with treatments in which cow dung was combined with NPK fertilizer compared to the control. It was observed that all growth parameters increased with increased levels of nutrient application. The growth parameters were high in pots treated with high rate combinations of organic and inorganic fertilizer and significantly different from either sole organic or inorganic nutrient sources or control. The results suggest that, application of $5 \mathrm{t} / \mathrm{ha}$ cow dung $+400 \mathrm{~kg} / \mathrm{ha}$ NPK fertilizer is recommended for fluted pumpkin production in Anyigba, but in terms of economic and environmental considerations, the application of $5 \mathrm{t} / \mathrm{ha}$ of cow dung $+250 \mathrm{~kg} / \mathrm{ha} \mathrm{NPK}$ is recommended.
\end{abstract}

Keywords: Fluted Pumpkin, Cattle Dung, NPK Fertilizer, Soil Physicochemical Properties, Nutrient Uptake.

\section{INTRODUCTION}

Organic manure has played a vital role in agricultural production in improving soil fertility, crop yield and quality. Soil organic fertilizers helps to improve the soil organic matter content thereby, enhancing the utilization of fertilizer and increasing crop yields. Rational fertilization, not only can enhance crop yields and improve the quality, but also can help to improve the soil fertility, and to maintain good environment [1].

It has been reported that Nitrogen $(\mathrm{N})$, Phosphorus $(\mathrm{P})$ and Potassium $(\mathrm{K})$ are the major essential elements required for physiological mechanisms for plant growth. $\mathrm{N}$ and $\mathrm{P}$ are usually the most limiting nutrients in many soils in Africa and are often simultaneously deficient [2]. With increasing pressure on soils of southern guinea savanna agroecological zone, shifting cultivation is no longer sustainable and traditional bush fallow period for maintaining the productivity of the soil has become shorter and soils are no longer able to supply the quantity of nutrients required with the result, that yield level declines rapidly once cropping commences [3]. Therefore, there is a need to augment soil fertility with external sources of nutrients. However, organic inputs alone will not meet the nutritional requirements of

Copyright @ 2020: This is an open-access article distributed under the terms of the Creative Commons Attribution license which permits unrestricted use, distribution, and reproduction in any medium for non commercial use (NonCommercial, or CC-BY-NC) provided the original author and source are credited. 
crops because they contain comparatively lower quantities of nutrients compared to inorganic fertilizers. Hence, the need to integrate the two forms in order to achieve better crop yields $[4,2]$.

Telfeiria occidentalis (fluted pumpkin) is one of the most important vegetables grown in southeastern Nigeria. It is generally regarded as leaf and seed vegetable [5]. It belongs to the family cucurbitaceae. Fluted pumpkin has about 90 genera and more than 70 species distributed all over the warm parts of the world [6]. Telfairia occidentalis is a dioecious, creeping perennial vegetable shrub that spreads low across the ground and climbs by means of befit and often coiled tendrils [7-9]. According to [10], Telfeiria occidentalis thrives well within the temperature range of $30-50^{\circ} \mathrm{C}$ while [9], reported that the tropical vine crop thrives under a warm environment with enough sunshine and prolonged rainy season. Rainfall appears to be the major factor in its productivity with a requirement of $1000-2500 \mathrm{~mm}$ per annum [11].

In order to sustain soil fertility over a long period of time, the use of organic manure is being advocated. This is because the nutrients contained in organic manures are released more slowly and are stored for a longer period of time in the soil, thereby ensuring a long residual effect [12]. Abou El-Magd, M. M et al., [13], also reported that manures provide a source of all necessary macro- and micronutrients in available forms, thereby improving the physical and biological properties of the soil. There are different types of organic manures including cow dung, compost, green and farm yard manure.

The quality of fluted pumpkin in terms of nutrient availability increases mostly when cultivated in good fertile soils rich in nitrogen, phosphorous and potassium [14]. In Nigeria, however, especially in the southeastern part, there is widespread problem of soil degradation due to continuous cultivation on the soils which is as a result of pressure from the increasing population of the area where the available land remains static. The situation is heightened because of imbalanced fertilizer use; due to the inability of the resource poor farmers to procure chemical fertilizers, farmers now realize the need for soil amendments by using available resources such as crop wastes; farmyard manure, cow dung and poultry waste [15]. However, the quantity and quality required of these materials limit their use. In addition, farmers appreciate the use of mineral fertilizers but their ever-increasing costs often prohibit their application at recommended rates [16]. Besides the pest challenges of fluted pumpkin, poor soil nutrients status constitute another setback for commercial optimum production of fluted pumpkin and other vegetable in Nigeria. This study evaluated the influence of combined application of cattle dung and NPK fertilizer (NPK 15 -15 -15) on soil physico-chemical properties, growth, nutrient uptake and yield of fluted pumpkin during the dry season of 2015 in Anyigba, Kogi State, Nigeria.

\section{Materials ANd Methods Study Location}

The experiment was conducted during the dry season of 2015 at Kogi State University, Anyigba, at Faculty of Agriculture Complex, Kogi State University, Anyigba (Lat. $7^{\circ} 29^{\prime} \mathrm{N}$ and Long. $7^{\circ} 11^{\prime} \mathrm{E}$ ) in the Guinea Savanna zone of Nigeria. Kogi State has a bimodal rainfall with peak pattern occurring in July and September. The mean annual rainfall is $1808 \mathrm{~mm}$ at Anyigba. The temperature shows some variation throughout the year with average monthly temperature of $17^{\circ} \mathrm{C}$ to $36.2^{\circ} \mathrm{C}$. Relative humidity is moderately high and varies from an average of $65-85 \%$ throughout the year.

\section{Treatments and Experimental Design}

Seven treatments with four replications were used for the experiment. The treatments were $250 \mathrm{~kg} / \mathrm{ha} \mathrm{NPK,} 2$ t/ha cattle dung, 2 t/ha cattle dung $+250 \mathrm{~kg} / \mathrm{ha}$ NPK, $3 \mathrm{t} / \mathrm{ha}$ cattle dung $+300 \mathrm{~kg} / \mathrm{ha} \mathrm{NPK}, 4 \mathrm{t} / \mathrm{ha}$ cattle dung $+350 \mathrm{~kg} / \mathrm{ha}$ NPK, $5 \mathrm{t} / \mathrm{ha}$ cattle dung $+400 \mathrm{~kg} / \mathrm{ha}$ NPK and control. The experiment was carried out during the dry season.

\section{Details of Experimentation}

A Completely Randomized Design (CRD) was used for the pot experiment. Top soil samples $(0-20 \mathrm{~cm})$, were collected from different points on a plot at the back of Soil Science Laboratory, Faculty of Agriculture Complex, Kogi State University Anyigba, with soil auger to a depth of 0-20 cm, and then bulked, before taking a composite sample. The soils were sieved through $4 \mathrm{~mm}$ sieve and ten kilograms $(10 \mathrm{~kg})$ of soil was weighed into each of 28 plastic pots and were arranged at random at a spacing of $50 \mathrm{~cm} \times 50 \mathrm{~cm}$. Composite soil samples were collected prior to application of cattle dung at a depth of 0-20 cm, air-dried, crushed and sieved with $2 \mathrm{~mm}$ mesh and then taken to the laboratory for physical and chemical analyses. Cattle dung was incorporated into the soil according to treatments two weeks before transplanting of fluted pumpkin (Telfairia occidentalis) seedlings in order to equilibrate properly with the soil. Seedlings obtained from National Institute of Horticultural Research (NIHORT) were transplanted one per pot, giving a total of 28 seedlings for the experiment.

\section{Soil Analysis}

Soil samples were collected from different points on a plot at the back of Soil Science Laboratory, Faculty of Agriculture Complex, Kogi State University Anyigba, with soil auger to a depth of 0-20 cm, for precropping soil physical and chemical properties. After harvest, soil samples were collected from the pots on the basis of treatments and 
were analyzed. A total of 28 soil samples were collected, prepared and analyzed. The following soil physical properties were also taken at 5-7 weeks after transplanting: gravimetric water content, soil bulk density and total soil porosity.

Bulk density and gravimetric water content were determined using the method of [17]. Total porosity was determined from the relationship between bulk density and particle density assuming a particle density value of $2.65 \mathrm{~g}$ $\mathrm{cm}^{-3}[18]$. Particle size distribution was determined by hydrometer method [19, 20].

The total nitrogen (TN) was determined using the Kjeldahl digestion method where the samples were digested with concentrated $\mathrm{H}_{2} \mathrm{SO}_{4}$ and titrated with $0.1 \mathrm{M}$ standard hydrochloric acid ( $\left.\mathrm{HCl}\right)$ [21]. Available phosphorus (P) was determined using [22] extraction procedure. The extracted $\mathrm{P}$ was read volumetrically at a wave length of $660 \mathrm{~mm}$ after the development of molybdenum blue colour. The electrical conductivity of the soil solution was taken using the EC electron [23]. The organic carbon was determined using the Walkley-Black wet oxidation method [24]. The exchangeable bases $\left(\mathrm{Ca}, \mathrm{Mg}, \mathrm{K}, \mathrm{Na}\right.$ ) were extracted with $1 \mathrm{M} \mathrm{NH}_{4} \mathrm{OAc}$ buffered at $\mathrm{pH} 7.0$ [25]. The pH of the soil solution in each beaker was taken using $\mathrm{pH}$ meter [26]. The exchangeable acidity $\left(\mathrm{Al}^{3+}\right.$ and $\left.\mathrm{H}^{+}\right)$were extracted with $\mathrm{Kcl}$ [25] and determined by titration with $0.05 \mathrm{M} \mathrm{NaOH}$ using phenolphthalein as indicator.

The cattle dung analysis was carried out in the Department of Biochemistry, Kogi State University. It was digested and subjected to chemical analysis to ascertain its $\mathrm{N}, \mathrm{P}, \mathrm{K}, \mathrm{Ca}, \mathrm{Mg}, \mathrm{Na}$, and Organic carbon content following the procedures that were outlined in the soil analysis section.

\section{Fertilizer Application}

A compound fertilizer (NPK-15:15:15) was applied once at 2 weeks after transplanting according to treatment; ring method of application was used.

\section{Weeding}

Weeds were controlled through hand pulling as the fluted pumpkins vines spread and covered the pots thus suppressing weed growth.

\section{Data Collection}

The plant's growth parameters were collected at two (2) weeks interval until harvesting. The plants growth parameters taken were; determination of number of leaves, stem girth $(\mathrm{cm})$, number of branches and internodes length. The plant biomasses were harvested and oven-dried at $60^{\circ} \mathrm{C}$ to constant weight for dry matter determination. The biomass was ground into powder using a ceramic pestle and mortar and was packed in a properly labeled polythene bag for chemical analysis.

\section{Statistical Analysis}

The agronomic traits of pumpkin were subjected to analysis of variance using GENSTAT Discovery Software. Significant means were separated using Duncan's Multiple Range Test (DMRT).

\section{ReSUlts AND Discussions}

\section{RESULTS}

\section{Precropping Soil Physical and Chemical Analyses}

The precropping soil chemical and physical properties of the experiment are presented in Table- 1 . The results reveal available $\mathrm{P}$ of $10.71 \mathrm{mg} / \mathrm{kg}, \mathrm{pH}(5.1)$, EC $(0.25 \mathrm{dS} / \mathrm{m})$, Organic carbon $(0.34 \mathrm{~g} / \mathrm{kg})$, Total N (0.02 g/kg), exchangeable $\mathrm{Mg}(2.63 \%), \mathrm{Ca}(4.04 \%), \mathrm{K}(2.17 \%), \mathrm{Na}(1.17 \%)$ ECEC (11.28 \%). The particle size distribution of the soil is sandy loam. 


Table-1: Precropping physico-chemical properties of the soil
\begin{tabular}{|c|c|}
\hline Properties & Values \\
\hline Sand $(\mathrm{g} / \mathrm{kg})$ & 78.80 \\
\hline Silt $(\mathrm{g} / \mathrm{kg})$ & 6.56 \\
\hline Clay $(\mathrm{g} / \mathrm{kg})$ & 14.64 \\
\hline Textural Class & Sandy loam \\
\hline $\mathrm{pH}\left(\mathrm{H}_{2} \mathrm{O}\right)$ & 5.1 \\
\hline Available P $(\mathrm{mg} / \mathrm{kg})$ & 10.71 \\
\hline EC dS/m & 0.25 \\
\hline Organic Carbon $(\mathrm{g} / \mathrm{kg})$ & 0.34 \\
\hline Total nitrogen $(\mathrm{g} / \mathrm{kg})$ & 0.02 \\
\hline Exchangable Cations \\
\hline Potassium $(\%)$ & 2.17 \\
\hline Calcium $(\%)$ & 4.04 \\
\hline Magnesium $(\%)$ & 2.63 \\
\hline Sodium $(\%)$ & 1.17 \\
\hline TEB $(\%)$ & 10.01 \\
\hline EA $(\%)$ & 1.27 \\
\hline ECEC $(\%)$ & 11.28 \\
\hline
\end{tabular}

The chemical composition of the cattle dung used for the experiment is presented in Table-2. The total N, OC, total $\mathrm{K}, \mathrm{Ca}, \mathrm{Mg}$ and $\mathrm{Na}$ were $1.20,2.93,2.07,5.82,3.70$ and $1.55 \%$ respectively. The exchangeable acidity value was $0.86 \%$.

Table-2: Chemical composition of cattle dung used for the experiment

\begin{tabular}{|c|c|}
\hline Properties & Values \\
\hline $\mathrm{pH}\left(\mathrm{H}_{2} \mathrm{O}\right)$ & 6.2 \\
\hline Available P (\%) & 3.16 \\
\hline Organic carbon (\%) & 2.93 \\
\hline Total N (\%) & 1.20 \\
\hline \multicolumn{2}{|c|}{ Exchangable Cations } \\
\hline Potassium (\%) & 2.07 \\
\hline Calcium (\%) & 5.82 \\
\hline Magnesium (\%) & 3.70 \\
\hline Sodium (\%) & 1.55 \\
\hline TEB (\%) & 13.11 \\
\hline EA (\%) & 0.86 \\
\hline
\end{tabular}

Effect of nutrient sources and rates on some selected soil physical properties

The effects of nutrient sources and rates on some selected soil physical properties are presented in Table-3. The results shows that nutrient sources had no significant effect $(\mathrm{p}=0.05)$ on bulk density, gravimetric water content, porosity, and volumetric water content in field experiments.

Table-3: Effects of Cattle dung and NPK fertilizer on some selected soil physical properties

\begin{tabular}{|l|l|l|l|l|}
\hline Treatments & $\begin{array}{l}\text { Bulk density } \\
\left(\mathbf{g} / \mathbf{c m}^{\mathbf{3}}\right)\end{array}$ & $\begin{array}{l}\text { Gravimetric water content } \\
(\mathbf{g} / \mathbf{g})\end{array}$ & $\begin{array}{l}\text { Porosity } \\
\left(\mathbf{c m}^{\mathbf{3}} / \mathbf{c m}^{\mathbf{3}}\right)\end{array}$ & $\begin{array}{l}\text { Volumetric water content } \\
\left(\mathbf{c m}^{\mathbf{3}} \mathbf{\mathbf { c m } ^ { \mathbf { 3 } }}\right)\end{array}$ \\
\hline $\mathrm{T}_{1}$ & 1.51 & 0.12 & 0.43 & 0.17 \\
\hline $\mathrm{T}_{2}$ & 1.33 & 0.12 & 0.48 & 0.16 \\
\hline $\mathrm{T}_{3}$ & 1.32 & 0.12 & 0.51 & 0.16 \\
\hline $\mathrm{T}_{4}$ & 1.34 & 0.13 & 0.50 & 0.18 \\
\hline $\mathrm{T}_{5}$ & 1.34 & 0.13 & 0.48 & 0.18 \\
\hline $\mathrm{T}_{6}$ & 1.30 & 0.13 & 0.51 & 0.17 \\
\hline $\mathrm{T}_{7}$ & 1.54 & 0.11 & 0.41 & 0.16 \\
\hline Mean & 1.38 & 0.12 & 0.47 & 0.17 \\
\hline $\mathrm{P}$ value & $\mathrm{NS}$ & $\mathrm{NS}$ & $\mathrm{NS}$ & $\mathrm{NS}$ \\
\hline
\end{tabular}

Note: $T_{1}=250 \mathrm{~kg} / \mathrm{ha} N P K, T_{2}=2 \mathrm{t} / \mathrm{ha}$ cattle dung, $\mathrm{T}_{3}=2 \mathrm{t} / \mathrm{ha}$ cattle dung $+250 \mathrm{~kg} / \mathrm{ha} \mathrm{NPK}, \mathrm{T}_{4}=3 \mathrm{t} / \mathrm{ha}$ cattle dung + $300 \mathrm{~kg} / \mathrm{ha} \mathrm{NPK}, \mathrm{T}_{5}=4 \mathrm{t} / \mathrm{ha}$ cattle dung $+350 \mathrm{~kg} / \mathrm{ha} \mathrm{NPK}, \mathrm{T}_{6}=5 \mathrm{t} / \mathrm{ha}$ cattle dung $+400 \mathrm{~kg} / \mathrm{ha} \mathrm{NPK}, \mathrm{T}_{7}=$ control, LSD Least Significant Difference. NS= Not Significant. 


\section{Effects of nutrient sources and rates on some selected soil physicochemical properties after harvest in the experiment}

The mean values of selected chemical properties and particle size distribution of soils planted to fluted pumpkin as influenced by nutrient sources and rates are presented Table-4.

Table-4: Effects of cattle dung and NPK fertilizer on physic-chemical properties of soil after harvest

\begin{tabular}{|c|c|c|c|c|c|c|c|c|}
\hline Soil properties & T1 & T2 & T3 & T4 & T5 & T6 & T7 & Mean \\
\hline Sand $(\mathrm{g} / \mathrm{kg})$ & 78.800 & 78.80 & 76.80 & 76.80 & 74.80 & 72.30 & 78.80 & 76.73 \\
\hline Silt $(\mathrm{g} / \mathrm{kg})$ & 4.56 & 6.56 & 8.56 & 6.65 & 4.56 & 5.06 & 4.56 & 5.77 \\
\hline Clay $(\mathrm{g} / \mathrm{kg})$ & 16.64 & 14.64 & 14.64 & 16.64 & 20.64 & 22.64 & 16.64 & 17.50 \\
\hline Textural class & SL & SL & Loam & Loam & Loam & Loam & Loam & SL \\
\hline $\mathrm{pH}(\mathrm{H} 2 \mathrm{O})$ & 5.62 & 5.61 & 5.68 & 5.71 & 5.73 & 5.74 & 5.13 & 5.64 \\
\hline $\mathrm{P}(\mathrm{mg} / \mathrm{kg})$ & 16.44 & 14.31 & 15.65 & 20.39 & 33.81 & 39.54 & 10.70 & 21.55 \\
\hline $\mathrm{EC}(\mathrm{dS} / \mathrm{m})$ & 0.21 & 0.21 & 0.23 & 0.23 & 0.23 & 0.24 & 0.16 & 0.21 \\
\hline $\mathrm{OC}(\mathrm{g} / \mathrm{kg})$ & 0.59 & 0.83 & 0.81 & 0.99 & 1.14 & 0.84 & 0.57 & 0.82 \\
\hline Total N $(\mathrm{g} / \mathrm{kg})$ & 0.03 & 0.04 & 0.05 & 0.06 & 0.07 & 0.07 & 0.03 & 0.05 \\
\hline $\mathrm{K}(\%)$ & 2.75 & 1.82 & 4.47 & 3.19 & 4.47 & 4.66 & 1.27 & 3.23 \\
\hline $\mathrm{Ca}(\%)$ & 3.99 & 3.60 & 4.77 & 3.96 & 4.62 & 5.15 & 3.48 & 4.22 \\
\hline $\mathrm{Mg}(\%)$ & 2.96 & 2.59 & 3.60 & 2.61 & 3.62 & 3.64 & 2.21 & 3.03 \\
\hline $\mathrm{Na}(\%)$ & 1.11 & 0.93 & 1.42 & 0.90 & 1.29 & 1.44 & 0.85 & 1.13 \\
\hline $\mathrm{TEB}(\%)$ & 10.80 & 8.93 & 14.25 & 11.19 & 14.00 & 14.89 & 7.81 & 11.71 \\
\hline $\mathrm{EA}(\%)$ & 1.25 & 1.57 & 0.93 & 1.29 & 1.00 & 0.75 & 1.81 & 1.23 \\
\hline $\mathrm{ECEC}(\%)$ & 12.04 & 10.39 & 15.18 & 11.96 & 15.00 & 15.64 & 9.83 & 12.87 \\
\hline
\end{tabular}

Note: $\mathrm{T} 1=250 \mathrm{~kg} / \mathrm{ha} \mathrm{NPK}, \mathrm{T} 2=2 \mathrm{t} / \mathrm{ha}$ cattle dung, T3 = $2 \mathrm{t} / \mathrm{ha}$ cattle dung $+250 \mathrm{~kg} / \mathrm{ha} \mathrm{NPK}, \mathrm{T} 4=3 \mathrm{t} / \mathrm{ha}$ cattle dung + $300 \mathrm{~kg} / \mathrm{ha}$ NPK, T5 = 4 t/ha cattle dung $+350 \mathrm{~kg} / \mathrm{ha} \mathrm{NPK}, \mathrm{T} 6=5 \mathrm{t} / \mathrm{ha}$ cattle dung $+400 \mathrm{~kg} / \mathrm{ha} \mathrm{NPK}, \mathrm{T} 7=\mathrm{control}, \mathrm{SL}=$ Sandy-loam.

\section{Effects of cattle dung and NPK fertilizers on nutrient uptake by fluted pumpkin}

The effects of nutrients sources and rates on nutrient uptake in the experiment are presented in Table 5. From the experiment, application of 4 t/ha cattle dung+350 kg/ha NPK (T5) and 5 t/ha cattle dung+400 kg/ha NPK (T6) gave the highest $\mathrm{N}$ uptake of $0.04 \mathrm{mg} / \mathrm{plant}$ which were not significantly $(\mathrm{P} \leq 0.05)$ different from other treatments and control in the experiment.

Application of $5 \mathrm{t} /$ ha cattle dung+400 kg/ha NPK (T6) gave the highest P uptake of $13.24 \mathrm{mg} / \mathrm{plant}$ which was not significantly $(\mathrm{P} \leq 0.05)$ different from $12.25 \mathrm{mg} /$ plant obtained from 4 t/ha cattle dung+350 $\mathrm{kg} / \mathrm{ha}$ NPK (T5) but was significantly $(\mathrm{P} \leq 0.05)$ higher than other treatments and control. Likewise, application of $3 \mathrm{t} / \mathrm{ha}$ cattle dung $+300 \mathrm{~kg} / \mathrm{ha}$ NPK (T4) gave $10.20 \mathrm{mg} /$ plant $\mathrm{P}$ uptake which was significantly $(\mathrm{P} \leq 0.05)$ higher than 8.22, 7.42, 7.21 and $5.33 \mathrm{mg} / \mathrm{plant}$ obtained from the application of $250 \mathrm{~kg} / \mathrm{ha}$ NPK (T1), $2 \mathrm{t} / \mathrm{ha}$ cattle dung+250 kg/ha NPK (T3), 2 t/ha cattle dung (T2) and control (T7), respectively. However, 8.22, 7.42 and $7.21 \mathrm{mg} /$ plant obtained from the application of $250 \mathrm{~kg} / \mathrm{ha}$ NPK (T1), $2 \mathrm{t} /$ ha cattle dung $+250 \mathrm{~kg} / \mathrm{ha}$ NPK (T3) and $2 \mathrm{t} /$ ha cattle dung (T2), respectively were not significantly (P $\leq 0.05)$ different but were significantly $(\mathrm{P} \leq 0.05)$ higher than $5.33 \mathrm{mg} /$ plant $\mathrm{P}$ uptake obtained from control (T7).

Application of $5 \mathrm{t} / \mathrm{ha}$ cattle dung+400 kg/ha NPK (T6) gave the highest K uptake of $4.22 \mathrm{mg} / \mathrm{plant}$ which was not significantly $(\mathrm{P} \leq 0.05)$ different from 4.03 and $4.01 \mathrm{mg} / \mathrm{plant}$ obtained from the application of $4 \mathrm{t} / \mathrm{ha}$ cattle dung +350 $\mathrm{kg} / \mathrm{ha}$ NPK (T5) and $2 \mathrm{t} / \mathrm{ha}$ cattle dung+250 kg/ha NPK (T3) but was significantly $(\mathrm{P} \leq 0.05)$ higher than other treatments and control. However, $3.01 \mathrm{mg} / \mathrm{plant} \mathrm{K}$ obtained from the application of $3 \mathrm{t} / \mathrm{ha}$ cattle dung+300 $\mathrm{kg} / \mathrm{ha} \mathrm{NPK}$ (T4) was significantly $(\mathrm{P} \leq 0.05)$ higher than $2.23,1.02$ and $0.84 \mathrm{mg} /$ plant obtained from the application of $250 \mathrm{~kg} / \mathrm{ha} \mathrm{NPK}(\mathrm{T} 1), 2$ t/ha cattle dung (T2) and control (T7), respectively. The application of $250 \mathrm{~kg} / \mathrm{ha} \mathrm{NPK}$ (T1) gave $2.23 \mathrm{mg} / \mathrm{plant} \mathrm{K} \mathrm{uptake}$ which was also significantly $(\mathrm{P} \leq 0.05)$ higher than 1.02 and 0.84 obtained from the application of 2 t/ha cattle dung $(\mathrm{T} 2)$ and control (T7), respectively. Application of 2 t/ha cattle dung (T2) and control (T7) gave 1.02 and $0.84 \mathrm{mg} / \mathrm{plant}$, respectively but was not significantly $(\mathrm{P} \leq 0.05)$ different from each other.

Application of $5 \mathrm{t} / \mathrm{ha}$ cattle dung+400 kg/ha NPK (T6) gave the highest Ca uptake of $5.21 \mathrm{mg} / \mathrm{plant}$ which was not significantly $(\mathrm{P} \leq 0.05)$ different from 4.79 and $4.60 \mathrm{mg} / \mathrm{plant}$ obtained from the application of $2 \mathrm{t} / \mathrm{ha}$ cattle dung +250 $\mathrm{kg} / \mathrm{ha}$ NPK (T3) and 4 t/ha cattle dung+350 kg/ha NPK (T5), respectively but was significantly $(\mathrm{P} \leq 0.05)$ higher than other treatments and control. However, application of $250 \mathrm{~kg} / \mathrm{ha}$ NPK (T1) gave $3.97 \mathrm{mg} / \mathrm{plant}$ Ca uptake but was not significantly $(\mathrm{P} \leq 0.05)$ different from $3.94,3.61$ and $3.45 \mathrm{mg} /$ plant obtained from $3 \mathrm{t} / \mathrm{ha}$ cattle dung+300 kg/ha NPK (T4), $2 \mathrm{t} /$ ha cattle dung (T2) and control (T7), respectively. 
In the experiment, application of $5 \mathrm{t} / \mathrm{ha}$ cattle dung+400 kg/ha NPK (T6) gave the highest Mg uptake of 3.65 $\mathrm{mg} /$ plant which was not significantly $(\mathrm{P} \leq 0.05)$ different from 3.63 and $3.62 \mathrm{mg} / \mathrm{plant}$ obtained from the application $4 \mathrm{t} / \mathrm{ha}$ cattle dung+350 kg/ha NPK (T5) and $2 \mathrm{t} / \mathrm{ha}$ cattle dung+250 kg/ha NPK (T3), respectively, but was significantly $(\mathrm{P} \leq 0.05)$ higher than other treatments and control. However, application of $250 \mathrm{~kg} / \mathrm{ha} \mathrm{NPK}(\mathrm{T} 1)$ gave $2.89 \mathrm{mg} / \mathrm{plant} \mathrm{Mg}$ uptake which was not significantly $(\mathrm{P} \leq 0.05)$ different from 2.60 and $2.5 \mathrm{mg} / \mathrm{plant}$ obtained from the application of $3 \mathrm{t} / \mathrm{ha}$ cattle dung+300 kg/ha NPK (T4) and 2 t/ha cattle dung (T2), respectively but was significantly $(\mathrm{P} \leq 0.05)$ higher than 2.23 $\mathrm{mg} /$ plant obtained from control (T7).

Application of $5 \mathrm{t} / \mathrm{ha}$ cattle dung+400 kg/ha NPK (T6) gave the highest Na uptake of $1.38 \mathrm{mg} / \mathrm{plant}$ which was not significantly $(\mathrm{P} \leq 0.05)$ different from $1.37 \mathrm{mg} / \mathrm{plant}$ obtained from 2 t/ha cattle dung+250 kg/ha NPK (T3) but was significantly $(\mathrm{P} \leq 0.05)$ higher than other treatments and control in. However, application of $4 \mathrm{t} / \mathrm{ha}$ cattle dung $+350 \mathrm{~kg} / \mathrm{ha}$ NPK (T5) gave $1.27 \mathrm{mg} /$ plant which was significantly $(\mathrm{P} \leq 0.05)$ higher than $1.10,0.72,0.71$, and $0.66 \mathrm{mg} / \mathrm{plant}$ obtained from the application of $250 \mathrm{~kg} / \mathrm{ha} \mathrm{NPK}$ (T1), $2 \mathrm{t} / \mathrm{ha}$ cattle dung (T2), $3 \mathrm{t} / \mathrm{ha}$ cattle dung+300 kg/ha NPK (T4) and control (T7), respectively. Further, $250 \mathrm{~kg} / \mathrm{ha}$ NPK (T1) gave $1.10 \mathrm{mg} /$ plant and was significantly $(\mathrm{P} \leq 0.05)$ higher than 0.72 , 0.71 , and $0.66 \mathrm{mg} /$ plant obtained from the application of $2 \mathrm{t} / \mathrm{ha}$ cattle dung (T2), $3 \mathrm{t} / \mathrm{ha}$ cattle dung+300 kg/ha NPK (T4) and control (T7), respectively. The $0.72,0.71$, and $0.66 \mathrm{mg} / \mathrm{plant} \mathrm{Na}$ uptake obtained from $2 \mathrm{t} / \mathrm{ha}$ cattle dung (T2), $3 \mathrm{t} / \mathrm{ha}$ cattle dung $+300 \mathrm{~kg} / \mathrm{ha}$ NPK (T4) and control (T7), respectively were not significantly $(\mathrm{P} \leq 0.05)$ different from each other.

Table-5: Effects of cattle dung and NPK fertilizer on nutrient uptake by fluted pumpkin in the experiment

\begin{tabular}{|l|l|l|l|l|l|l|}
\hline Treatments & $\mathbf{N ~ m g / p l a n t ~}$ & $\mathbf{P}$ mg/plant & K mg/plant & Ca mg/plant & Mg mg/plant & Na mg/plant \\
\hline T1 & 0.02 & $8.22^{\mathrm{c}}$ & $2.23^{\mathrm{c}}$ & $3.97^{\mathrm{b}}$ & $2.89^{\mathrm{b}}$ & $1.10^{\mathrm{c}}$ \\
\hline T2 & 0.01 & $7.21^{\mathrm{c}}$ & $1.02^{\mathrm{d}}$ & $3.61^{\mathrm{b}}$ & $2.58^{\mathrm{b}, \mathrm{c}}$ & $0.72^{\mathrm{d}}$ \\
\hline T3 & 0.03 & $7.42^{\mathrm{c}}$ & $4.01^{\mathrm{a}}$ & $4.79^{\mathrm{a}}$ & $3.62^{\mathrm{a}}$ & $1.37^{\mathrm{a}}$ \\
\hline T4 & 0.03 & $10.20^{\mathrm{b}}$ & $3.01^{\mathrm{b}}$ & $3.95^{\mathrm{b}}$ & $2.60^{\mathrm{b}, \mathrm{c}}$ & $0.71^{\mathrm{d}}$ \\
\hline T5 & 0.04 & $12.25^{\mathrm{a}}$ & $4.03^{\mathrm{a}}$ & $4.60^{\mathrm{a}}$ & $3.63^{\mathrm{a}}$ & $1.27^{\mathrm{b}}$ \\
\hline T6 & 0.04 & $13.24^{\mathrm{a}}$ & $4.22^{\mathrm{a}}$ & $5.21^{\mathrm{a}}$ & $3.65^{\mathrm{a}}$ & $1.38^{\mathrm{a}}$ \\
\hline T7(control) & 0.01 & $5.33^{\mathrm{d}}$ & $0.84^{\mathrm{d}}$ & $3.45^{\mathrm{b}}$ & $2.23^{\mathrm{c}}$ & $0.66^{\mathrm{d}}$ \\
\hline Mean & 0.03 & 9.12 & 2.77 & 4.23 & 3.03 & 1.03 \\
\hline LSD(P $\leq 0.05)$ & 0.00 & 1.62 & 0.59 & 0.64 & 0.38 & 0.07 \\
\hline
\end{tabular}

Note: Means followed by same letter(s) in a column are not significantly different $(\mathrm{P} \leq 0.05)$.

$\mathrm{T} 1=250 \mathrm{~kg} / \mathrm{ha}$ NPK, T2 $=2 \mathrm{t} / \mathrm{ha}$ cattle dung, T3 $=2 \mathrm{t} / \mathrm{ha} \mathrm{cow} \mathrm{dung}+250 \mathrm{~kg} / \mathrm{ha} \mathrm{NPK}, \mathrm{T} 4=3 \mathrm{t} / \mathrm{ha}$ cattle dung +300 $\mathrm{kg} / \mathrm{ha} \mathrm{NPK}, \mathrm{T} 5=4 \mathrm{t} / \mathrm{ha}$ cattle dung $+350 \mathrm{~kg} / \mathrm{ha} \mathrm{NPK}, \mathrm{T} 6=5 \mathrm{t} / \mathrm{ha}$ cattle dung $+400 \mathrm{~kg} / \mathrm{ha} \mathrm{NPK}, \mathrm{T} 7=\mathrm{control}, \mathrm{LSD}-$ Least Significant Difference

\section{Effects of organic and inorganic fertilizer on number of leaves of fluted pumpkin}

From table-6, at two weeks after transplanting (2 WAT), application of $5 \mathrm{t} / \mathrm{ha}$ cattle dung+400 kg/ha NPK (T6) gave the highest number of leaves of 35.00 which was not significantly $(\mathrm{P} \leq 0.05)$ different from 34.50 obtained from 4 $\mathrm{t} /$ ha cattle dung $+350 \mathrm{~kg} / \mathrm{ha}$ NPK (T5) but was significantly different from other treatments and control. Also, application of $3 \mathrm{t} / \mathrm{ha}$ cattle dung $+300 \mathrm{~kg} / \mathrm{ha}$ NPK $(\mathrm{T} 4)$ gave 29.75 number of leaves which was not significantly $(\mathrm{P} \leq 0.05)$ different from 28.00 and 25.50 obtained from 2 t/ha cattle dung+250 kg/ha NPK (T3) and $2 \mathrm{t} /$ ha cattle dung (T2) respectively but was significantly $(\mathrm{P} \leq 0.05)$ higher than 19.50 and 19.50 obtained in $250 \mathrm{~kg} / \mathrm{ha} \mathrm{NPK}(\mathrm{T} 1)$ and control (T7). The trend with $\mathrm{T} 1$ and $\mathrm{T} 7$ was obvious; they had the same number of leaves.

At 4 WAT, application of 5 t/ha cattle dung+400 kg/ha NPK (T6) gave the highest number of leaves of 77.25 which was significantly $(\mathrm{P} \leq 0.05)$ higher than other treatments and control. Similarly, application of $4 \mathrm{t} / \mathrm{ha}$ cattle dung+350 kg/ha NPK (T5) gave a higher number of leaves of 74.25 which was significantly $(\mathrm{P} \leq 0.05)$ higher than 67.75 , $65.75,61.25,50.50$ and 50.25 number of leaves obtained from 2 t/ha cow dung+250 kg/ha NPK (T3), 3 t/ha cattle dung+300 kg/ha NPK (T4), 2 t/ha cattle dung (T2), $250 \mathrm{~kg} / \mathrm{ha}$ NPK (T1) and control (T7), respectively. However, 67.75 and 65.75 number of leaves obtained from $2 \mathrm{t} / \mathrm{ha}$ cattle dung+250 kg/ha NPK (T3) and $3 \mathrm{t} / \mathrm{ha}$ cattle dung+300 kg/ha NPK (T4) were not significant $(\mathrm{P} \leq 0.05)$ difference. Application of $2 \mathrm{t} / \mathrm{ha}$ cattle dung (T2) gave 61.25 number of leaves which was also significantly $(\mathrm{P} \leq 0.05)$ higher than $250 \mathrm{~kg} / \mathrm{ha}$ NPK $(\mathrm{T} 1)$ and control (T7) with values of 50.50 and 50.25 . Application of $250 \mathrm{~kg} / \mathrm{ha} \mathrm{NPK} \mathrm{(T1)} \mathrm{and} \mathrm{control} \mathrm{(T7)} \mathrm{with} \mathrm{values} \mathrm{of} 50.50$ and 50.25, respectively were not significantly $(\mathrm{P} \leq 0.05)$ different.

At 6 WAT, application of $5 \mathrm{t} /$ ha cattle dung+400 kg/ha NPK (T6) gave the highest number of leaves of 105.25 which was significantly $(\mathrm{P} \leq 0.05)$ higher than other treatments and control. Furthermore, 101.75 number of leaves obtained from the application of $4 \mathrm{t} / \mathrm{ha}$ cattle dung $+350 \mathrm{~kg} / \mathrm{ha}$ NPK (T5) was also significantly $(\mathrm{P} \leq 0.05)$ higher than 96.75, 95.25, 91.75, 91.25 and 81.50 obtained from the application of 2 t/ha cattle dung+250 kg/ha NPK (T3), $3 \mathrm{t} / \mathrm{ha}$ cattle dung+300 kg/ha NPK (T4), $250 \mathrm{~kg} / \mathrm{ha}$ NPK (T1), 2 t/ha cattle dung (T2) and control (T7), respectively. However, 96.75 and 95.25 obtained in 2 t/ha cattle dung+250 kg/ha NPK (T3) and 3 t/ha cattle dung+300 kg/ha NPK (T4), 
respectively were not significantly $(\mathrm{P} \leq 0.05)$ different but were significantly $(\mathrm{P} \leq 0.05)$ higher than $250 \mathrm{~kg} / \mathrm{ha}$ NPK $(\mathrm{T} 1), 2$ t/ha cattle dung (T2) and control (T7). Also, 91.75 and 91.25 number of leaves obtained from application of T1 $(250 \mathrm{~kg} / \mathrm{ha} \mathrm{NPK})$ and T2 $(2 \mathrm{t} / \mathrm{ha}$ cow dung) were not significantly $(\mathrm{P} \leq 0.05)$ different but were significantly $(\mathrm{P} \leq 0.05)$ higher than 81.50 in control (T7).

At 8 WAT, application of $5 \mathrm{t} /$ ha cattle dung+400 kg/ha NPK (T6) gave the highest number of leaves of 155.50 which was significantly $(\mathrm{P} \leq 0.05)$ higher than other treatments and control. Likewise, 146.50 number of leaves obtained from $4 \mathrm{t} / \mathrm{ha}$ cattle dung $+350 \mathrm{~kg} / \mathrm{ha}$ NPK (T5) was also significantly $(\mathrm{P} \leq 0.05)$ higher than $136.0,135.25,125.0,118.75$ and 105.25 number of leaves obtained from $3 \mathrm{t} / \mathrm{ha}$ cattle dung+300 kg/ha NPK (T4), $2 \mathrm{t} / \mathrm{ha}$ cattle dung+250 kg/ha NPK (T3), $250 \mathrm{~kg} / \mathrm{ha} \mathrm{NPK}$ (T1), 2 t/ha cattle dung (T2) and control (T7), respectively. However, 136.0 and 135.25 number of leaves obtained from $3 \mathrm{t} / \mathrm{ha}$ cattle dung+300 kg/ha NPK (T4) and 2 t/ha cattle dung+250 kg/ha NPK (T3) were not significantly $(\mathrm{P} \leq 0.05)$ different. Application of $250 \mathrm{~kg} / \mathrm{ha}$ NPK $(\mathrm{T} 1)$ gave 125.0 number of leaves which was also significantly $(\mathrm{P} \leq 0.05)$ higher than 118.75 and 105.25 number of leaves obtained in $2 \mathrm{t} /$ ha cattle dung (T2) and control (T7), respectively. Also, 118.75 number of leaves obtained in $2 \mathrm{t} /$ ha cattle dung (T2) was also significantly $(\mathrm{P} \leq 0.05)$ higher than105.25 in control (T7).

At 10 WAT, application of 5 t/ha cattle dung+400 kg/ha NPK (T6) gave the highest number of leaves of 178.50 which was significantly $(\mathrm{P} \leq 0.05)$ higher than other treatments and control. Likewise, 170.75 number of leaves obtained from $4 \mathrm{t} /$ ha cattle dung $+350 \mathrm{~kg} / \mathrm{ha}$ NPK (T5) was also significantly $(\mathrm{P} \leq 0.05)$ higher than $163.75,158.0,151.0,142.0$ and 125.75 number of leaves obtained from the application of $3 \mathrm{t} / \mathrm{ha}$ cattle dung+300 kg/ha NPK (T4), $2 \mathrm{t} / \mathrm{ha}$ cattle dung+250 $\mathrm{kg} / \mathrm{ha}$ NPK (T3), $250 \mathrm{~kg} / \mathrm{ha}$ NPK (T1), 2 t/ha cattle dung (T2) and control (T7), respectively. Application of $3 \mathrm{t} / \mathrm{ha}$ cattle dung+300 kg/ha NPK (T4) which gave 163.75 number of leaves was also significantly $(\mathrm{P} \leq 0.05)$ higher than 158.0 , 151.0, 142.0 and 125.75 number of leaves obtained from $2 \mathrm{t} / \mathrm{ha}$ cattle dung+250 kg/ha NPK (T3), $250 \mathrm{~kg} / \mathrm{ha} \mathrm{NPK}$ (T1), 2 t/ha cattle dung (T2) and control (T7), respectively. Application of 2 t/ha cattle dung+250 kg/ha NPK (T3) gave 158.0 number of leaves which was also significantly $(\mathrm{P} \leq 0.05)$ higher than $151.0,142.0$ and 125.75 obtained in $250 \mathrm{~kg} / \mathrm{ha} \mathrm{NPK}$ (T1), 2 t/ha cattle dung (T2) and control (T7), respectively. The 151.75 number of leaves obtained from application of $250 \mathrm{~kg} / \mathrm{ha}$ NPK (T1) was also significantly $(\mathrm{P} \leq 0.05)$ higher than 142.0 and 125.75 number of leaves obtained from $2 \mathrm{t} / \mathrm{ha}$ cattle dung (T2) and control (T7), respectively. Similarly, 142.0 obtained in 2 t/ha cattle dung (T2) was also significantly $(\mathrm{P} \leq 0.05)$ higher compared to 125.75 obtained in control $(\mathrm{T} 7)$.

At 12 WAT, application of 5 t/ha cattle dung+400 kg/ha NPK (T6) gave the highest number of leaves of 179.50 which was significantly $(\mathrm{P} \leq 0.05)$ higher than other treatments and control. Likewise, 172.25 number of leaves obtained from $4 \mathrm{t} /$ ha cattle dung $+350 \mathrm{~kg} / \mathrm{ha}$ NPK (T5) was also significantly $(\mathrm{P} \leq 0.05)$ higher than $166.25,159.75,154.75,144.0$ and 126.25 obtained from the application of $3 \mathrm{t} / \mathrm{ha}$ cattle dung+300 kg/ha NPK (T4), $2 \mathrm{t} / \mathrm{ha}$ cattle dung+250 kg/ha NPK (T3), $250 \mathrm{~kg} / \mathrm{ha}$ NPK (T1), $2 \mathrm{t} / \mathrm{ha}$ cattle dung (T2) and control (T7), respectively. Application of $3 \mathrm{t} / \mathrm{ha}$ cattle dung+300 $\mathrm{kg} /$ ha NPK (T4) which gave 166.75 number of leaves was also significantly $(\mathrm{P} \leq 0.05)$ higher than $159.75,154.75,144.0$ and 126.25 obtained from 2 t/ha cattle dung+250 kg/ha NPK (T3), $250 \mathrm{~kg} / \mathrm{ha} \mathrm{NPK} \mathrm{(T1),} 2$ t/ha cattle dung (T2) and control (T7), respectively. Application of $2 \mathrm{t} / \mathrm{ha}$ cattle dung+250 kg/ha NPK (T3) gave 159.75 number of leaves which was also significantly $(\mathrm{P} \leq 0.05)$ higher than $154.75,144.0$ and 126.25 obtained in $250 \mathrm{~kg} / \mathrm{ha} \mathrm{NPK}(\mathrm{T} 1), 2 \mathrm{t} / \mathrm{ha}$ cattle dung (T2) and control (T7), respectively. The 154.75 number of leaves obtained from application of $250 \mathrm{~kg} / \mathrm{ha} \mathrm{NPK}$ (T1) was also significantly $(\mathrm{P} \leq 0.05)$ higher than 144.0 and 126.25 number of leaves obtained from 2 t/ha cattle dung (T2) and control (T7), respectively. Similarly, 144.0 obtained in 2 t/ha cattle dung (T2) was also significantly $(\mathrm{P} \leq 0.05)$ higher compared to 126.25 obtained in control (T7).

Table-6: Effects of organic and inorganic fertilizer on number of leaves per stand of fluted pumpkin during the dry season of 2015

\begin{tabular}{|c|c|c|c|c|c|c|}
\hline Treatments & 2WAT & 4WAT & 6WAT & 8WAT & $10 \mathrm{WAT}$ & $12 \mathrm{WAT}$ \\
\hline $\mathrm{T} 1$ & $19.50^{\mathrm{c}}$ & $50.50^{\mathrm{e}}$ & $91.75^{\mathrm{d}}$ & $125.0^{\mathrm{d}}$ & $151.75^{\mathrm{e}}$ & $154.75^{\mathrm{e}}$ \\
\hline $\mathrm{T} 2$ & $25.50^{\mathrm{b}, \mathrm{c}}$ & $61.25^{\mathrm{d}}$ & $91.25^{\mathrm{d}}$ & $118.75^{\mathrm{e}}$ & $142.00^{\mathrm{f}}$ & $144.00^{f}$ \\
\hline T3 & $28.00^{\mathrm{b}}$ & $67.75^{\mathrm{c}}$ & $96.75^{\mathrm{c}}$ & $135.25^{\mathrm{c}}$ & $158.00^{\mathrm{d}}$ & $159.75^{d}$ \\
\hline $\mathrm{T} 4$ & $29.75^{b}$ & $65.75^{\mathrm{c}}$ & $95.25^{\mathrm{c}}$ & $136.00^{\mathrm{c}}$ & $163.75^{\mathrm{c}}$ & $166.25^{\mathrm{c}}$ \\
\hline T5 & $34.50^{\mathrm{a}}$ & $74.25^{\mathrm{b}}$ & $101.75^{b}$ & $146.50^{\mathrm{b}}$ & $170.75^{b}$ & $172.25^{b}$ \\
\hline T6 & $35.00^{\mathrm{a}}$ & $77.25^{\mathrm{a}}$ & $105.25^{\mathrm{a}}$ & $155.50^{\mathrm{a}}$ & $178.50^{\mathrm{a}}$ & $179.25^{\mathrm{a}}$ \\
\hline T7 (control) & $19.50^{\mathrm{c}}$ & $50.25^{\mathrm{e}}$ & $81.50^{\mathrm{e}}$ & $105.25^{\mathrm{f}}$ & $125.75^{\mathrm{g}}$ & $126.25^{\mathrm{g}}$ \\
\hline Mean & 27.39 & 63.86 & 94.79 & 131.75 & 155.79 & 157.50 \\
\hline $\mathrm{LSD}(\mathrm{P} \leq 0.05)$ & 3.03 & 2.86 & 2.75 & 5.54 & 4.33 & 3.88 \\
\hline
\end{tabular}

Note: Means followed by same letter(s) in a column are not significantly different $(\mathrm{P} \leq 0.05)$.

$\mathrm{T} 1=250 \mathrm{~kg} / \mathrm{ha}$ NPK, T2 $=2 \mathrm{t} / \mathrm{ha}$ cattle dung, T3 = $2 \mathrm{t} / \mathrm{ha}$ cow dung $+250 \mathrm{~kg} / \mathrm{ha} \mathrm{NPK}, \mathrm{T} 4=3 \mathrm{t} / \mathrm{ha}$ cattle dung +300 $\mathrm{kg} / \mathrm{ha}$ NPK, T5 = $4 \mathrm{t} / \mathrm{ha}$ cattle dung $+350 \mathrm{~kg} / \mathrm{ha} \mathrm{NPK,} \mathrm{T6}=5 \mathrm{t} / \mathrm{ha}$ cattle dung $+400 \mathrm{~kg} / \mathrm{ha} \mathrm{NPK}, \mathrm{T} 7=$ control, LSD Least Significant Difference 


\section{Effects of organic and inorganic fertilizers on number of branches of fluted pumpkin}

From Table-7, at 2 WAT, there were no significant $(\mathrm{P} \leq 0.05)$ differences among all treatments and control in number of branches. At 4 WAT, application of $2 \mathrm{t} / \mathrm{ha}$ cattle dung+250 kg/ha NPK (T3), $3 \mathrm{t} / \mathrm{ha}$ cattle dung+3000 kg/ha NPK (T4), 4 t/ha cattle dung+350 kg/ha NPK (T5) and 5 t/ha cattle dung+400 kg/ha NPK (T6) gave the highest number of branches of 2.50 which was not significantly $(\mathrm{P} \leq 0.05)$ different from 2.0 number of branches obtained from $250 \mathrm{~kg} / \mathrm{ha}$ NPK (T1) and $2 \mathrm{t} /$ ha cattle dung (T2) but significantly $(\mathrm{P} \leq 0.05)$ higher than 1.75 obtained from control (T7).

At $6 \mathrm{WAT}$, application of $5 \mathrm{t} / \mathrm{ha}$ cattle dung+400 kg/ha NPK (T6) gave the highest number of branches of 3.50 which was not significantly $(\mathrm{P} \leq 0.05)$ higher than 3.25 and 3.25 obtained from $2 \mathrm{t} / \mathrm{ha}$ cattle dung+250 kg/ha NPK (T3) and $3 \mathrm{t} / \mathrm{ha}$ cattle dung+300 kg/ha NPK (T4). Also, application of $4 \mathrm{t} / \mathrm{ha}$ cattle dung+350 kg/ha NPK (T5) that gave 3.00 number of branches was not significantly $(\mathrm{P} \leq 0.05)$ different from $250 \mathrm{~kg} / \mathrm{ha}$ NPK $(\mathrm{T} 1), 2 \mathrm{t} / \mathrm{ha}$ cattle dung (T2) and control (T7) with values of $2.75,2.25$ and 2.25 , respectively.

At 8 WAT, application of $5 \mathrm{t} / \mathrm{ha}$ cattle dung+400 kg/ha NPK (T6) gave the highest number of branches of 4.50 but was not significantly $(\mathrm{P} \leq 0.05)$ different from 4.25 and 4.00 obtained from $3 \mathrm{t} / \mathrm{ha}$ cattle dung+300 kg/ha NPK (T4) and $4 \mathrm{t} / \mathrm{ha}$ cattle dung+350 kg/ha NPK (T5), respectively. Also, application of $2 \mathrm{t} / \mathrm{ha}$ cattle dung+250 kg/ha NPK (T3) gave 3.50 number of branches but was not significantly $(\mathrm{P} \leq 0.05)$ difference from 3.00 obtained from $250 \mathrm{~kg} / \mathrm{ha} \mathrm{NPK}$ (T1) but was significantly $(\mathrm{P} \leq 0.05)$ higher than $2 \mathrm{t} /$ ha cattle dung (T2) and control (T7) with values of 2.50 and 2.25 , respectively. However, 2.50 obtained from $2 \mathrm{t} /$ ha cattle dung (T2) and 2.25 number of branches from control (T7) were not significantly $(\mathrm{P} \leq 0.05)$ different from each other.

At $10 \mathrm{WAT}$, application of $3 \mathrm{t} / \mathrm{ha}$ cattle dung+300 kg/ha NPK (T4) gave the highest number of branches of 5.75 which was not significantly $(\mathrm{P} \leq 0.05)$ different from 5.50 and 5.50 obtained from $4 \mathrm{t} /$ ha cattle dung $+350 \mathrm{~kg} / \mathrm{ha}$ NPK $(\mathrm{T} 5)$ and $5 \mathrm{t} / \mathrm{ha}$ cattle dung+400 kg/ha NPK (T6), respectively but was significantly $(\mathrm{P} \leq 0.05)$ higher than other treatments and control. Also, application of $2 \mathrm{t} / \mathrm{ha}$ cattle dung+250 kg/ha NPK (T3) gave 4.50 number of branches but was not significantly $(\mathrm{P} \leq 0.05)$ different from 3.75 obtained from $250 \mathrm{~kg} / \mathrm{ha}$ NPK (T1) but was significantly $(\mathrm{P} \leq 0.05)$ higher than $2 \mathrm{t} /$ ha cattle dung (T2) and control (T7) with values of 3.25 and 3.00 number of branches, respectively. However, 3.25 obtained from $2 \mathrm{t} /$ ha cattle dung (T2) and 3.00 number of branches from control (T7) were not significantly (P $\leq 0.05)$ different from each other.

At $12 \mathrm{WAT}$, application of $3 \mathrm{t} / \mathrm{ha}$ cattle dung+300 kg/ha NPK (T4) gave the highest number of branches of 5.75 which was not significantly $(\mathrm{P} \leq 0.05)$ different from 5.50 and 5.50 obtained from $4 \mathrm{t} /$ ha cattle dung+350 kg/ha NPK (T5) and $5 \mathrm{t} /$ ha cattle dung $+400 \mathrm{~kg} / \mathrm{ha}$ NPK (T6), respectively but was significantly $(\mathrm{P} \leq 0.05)$ higher than other treatments and control. Also, application of $2 \mathrm{t} / \mathrm{ha}$ cattle dung+250 kg/ha NPK (T3) gave 4.50 number of branches which was not significantly ( $\mathrm{P} \leq 0.05)$ different from 3.75 obtained from $250 \mathrm{~kg} / \mathrm{ha}$ NPK $(\mathrm{T} 1)$ but was significantly different from $2 \mathrm{t} / \mathrm{ha}$ cattle dung (T2) and control (T7) with values of 3.25 and 3.00, respectively. However, 3.25 obtained from 2 t/ha cattle dung (T2) and 3.00 number of branches from control (T7) were not significantly $(\mathrm{P} \leq 0.05)$ different from each other.

Table-7: Effect of organic and inorganic fertilizers on number of branches of fluted pumpkin during the dry season of 2015

\begin{tabular}{|l|l|l|l|l|l|l|}
\hline Treatments & 2WAT & 4WAT & 6WAT & 8WAT & 10WAT & 12WAT \\
\hline T1 & 1.00 & $2.00^{\mathrm{a}, \mathrm{b}}$ & $2.75^{\mathrm{b}}$ & $3.00^{\mathrm{b}}$ & $3.75^{\mathrm{b}}$ & $3.75^{\mathrm{b}}$ \\
\hline T2 & 1.00 & $2.00^{\mathrm{a}, \mathrm{b}}$ & $2.25^{\mathrm{b}}$ & $2.50^{\mathrm{c}}$ & $3.25^{\mathrm{c}}$ & $3.25^{\mathrm{c}}$ \\
\hline T3 & 1.50 & $2.50^{\mathrm{a}}$ & $3.25^{\mathrm{a}}$ & $3.50^{\mathrm{b}}$ & $4.50^{\mathrm{b}}$ & $4.50^{\mathrm{b}}$ \\
\hline T4 & 1.50 & $2.50^{\mathrm{a}}$ & $3.25^{\mathrm{a}}$ & $4.25^{\mathrm{a}}$ & $5.75^{\mathrm{a}}$ & $5.75^{\mathrm{a}}$ \\
\hline T5 & 1.25 & $2.50^{\mathrm{a}}$ & $3.00^{\mathrm{b}}$ & $4.00^{\mathrm{a}}$ & $5.50^{\mathrm{a}}$ & $5.50^{\mathrm{a}}$ \\
\hline T6 & 1.50 & $2.50^{\mathrm{a}}$ & $3.50^{\mathrm{a}}$ & $4.50^{\mathrm{a}}$ & $5.50^{\mathrm{a}}$ & $5.50^{\mathrm{a}}$ \\
\hline T7 (control) & 1.00 & $1.75^{\mathrm{b}}$ & $2.25^{\mathrm{b}}$ & $2.25^{\mathrm{c}}$ & $3.00^{\mathrm{c}}$ & $3.00^{\mathrm{c}}$ \\
\hline Mean & 1.25 & 2.21 & 2.89 & 3.43 & 4.46 & 4.46 \\
\hline LSD(P $\leq 0.05)$ & 0.62 & 0.68 & 1.05 & 0.86 & 0.86 & 0.86 \\
\hline
\end{tabular}

Note: Means followed by same letter(s) in a column are not significantly different $(\mathrm{P} \leq 0.05)$.

$\mathrm{T} 1=250 \mathrm{~kg} / \mathrm{ha}$ NPK, T2 = $2 \mathrm{t} / \mathrm{ha}$ cattle dung, T3 $=2 \mathrm{t} / \mathrm{ha}$ cow dung $+250 \mathrm{~kg} / \mathrm{ha} \mathrm{NPK}, \mathrm{T} 4=3 \mathrm{t} / \mathrm{ha}$ cattle dung +300 $\mathrm{kg} / \mathrm{ha}$ NPK, T5 = $4 \mathrm{t} / \mathrm{ha}$ cattle dung $+350 \mathrm{~kg} / \mathrm{ha}$ NPK, T6 $=5 \mathrm{t} / \mathrm{ha}$ cattle dung $+400 \mathrm{~kg} / \mathrm{ha} \mathrm{NPK}, \mathrm{T} 7=$ control, LSD Least Significant Difference

\section{Effect of organic and inorganic fertilizer on stem girth $(\mathrm{cm})$ of fluted pumpkin during the dry season of 2015}

From Table-8, 2 WAT, application of $3 \mathrm{t} / \mathrm{ha}$ cattle dung+300 kg/ha NPK (T4) gave the best stem girth of 1.20 $\mathrm{cm}$ which was not significantly $(\mathrm{P} \leq 0.05)$ different from $1.15,1.10,1.10,1.10$ and $1.08 \mathrm{~cm}$ obtained from $2 \mathrm{t} / \mathrm{ha}$ cattle dung+250 kg/ha NPK (T3), 5 t/ha cattle dung+400 kg/ha NPK (T6), 4 t/ha cattle dung+350 kg/ha NPK (T5), 2 t/ha cattle 
dung (T2) and $250 \mathrm{~kg} / \mathrm{ha}$ NPK (T1), respectively but was significantly $(\mathrm{P} \leq 0.05)$ higher than $1.00 \mathrm{~cm}$ obtained from control (T7).

At 4 WAT, application of $3 \mathrm{t} / \mathrm{ha}$ cattle dung+300 kg/ha NPK (T4) gave the best stem girth of $1.70 \mathrm{~cm}$ which was not significantly $(\mathrm{P} \leq 0.05)$ different from 1.65 and $1.60 \mathrm{~cm}$ obtained from $2 \mathrm{t} / \mathrm{ha}$ cattle dung+350 $\mathrm{kg} / \mathrm{ha} \mathrm{NPK}(\mathrm{T} 3)$ and 5 t/ha cattle dung+400 kg/ha NPK (T6), respectively. Likewise, application of 4 t/ha cattle dung+350 kg/ha NPK (T5) gave $1.55 \mathrm{~cm}$ stem girth which was not significantly $(\mathrm{P} \leq 0.05)$ different from $1.55,1.50$ and $1.48 \mathrm{~cm}$ obtained from $2 \mathrm{t} / \mathrm{ha}$ cattle dung (T2), $250 \mathrm{~kg} / \mathrm{ha}$ NPK (T1) and control (T7), respectively.

At 6 WAT, application of 4 t/ha cattle dung+350 kg/ha NPK (T5) gave the best stem girth of $2.43 \mathrm{~cm}$ which was not significantly $(\mathrm{P} \leq 0.05)$ different from $2.40 \mathrm{~cm}$ obtained from $3 \mathrm{t} / \mathrm{ha}$ cattle dung $+300 \mathrm{~kg} / \mathrm{ha} \mathrm{NPK}$ (T4). Similarly, application of $2 \mathrm{t} / \mathrm{ha}$ cattle dung+250 kg/ha NPK (T3) and $5 \mathrm{t} / \mathrm{ha}$ cattle dung+400 kg/ha NPK (T6) gave 2.08 and $2.08 \mathrm{~cm}$ respectively which were not significantly $(\mathrm{P} \leq 0.05)$ different from each other but significantly $(\mathrm{P} \leq 0.05)$ higher than 1.73 $\mathrm{cm}$ obtained in control (T7). On the other hand, 1.75, 1.73 and $1.73 \mathrm{~cm}$ obtained from $250 \mathrm{~kg} / \mathrm{ha}$ NPK (T1), $2 \mathrm{t} / \mathrm{ha}$ cattle dung (T2) and control (T7), respectively were not significantly $(\mathrm{P} \leq 0.05)$ different.

At 8 WAT, application of $3 \mathrm{t} / \mathrm{ha}$ cattle dung+300 kg/ha NPK (T4) gave the best stem girth of $3.23 \mathrm{~cm}$ which was not significantly $(\mathrm{P} \leq 0.05)$ different from 3.20 and $3.08 \mathrm{~cm}$ obtained from $4 \mathrm{t} / \mathrm{ha}$ cattle dung+350 kg/ha NPK (T5) and 5 t/ha cattle dung+400 kg/ha NPK (T6), respectively. Also, application of 2 t/ha cattle dung+250 kg/ha NPK (T3) gave $2.85 \mathrm{~cm}$ stem girth which was also significantly $(\mathrm{P} \leq 0.05)$ higher than $2.35,2.15$ and $2.23 \mathrm{~cm}$ obtained from $250 \mathrm{~kg} / \mathrm{ha}$, NPK (T1), 2 t/ha cattle dung (T2) and control (T7), respectively. On the other hand, 2.35 and $2.23 \mathrm{~cm}$ stem girth obtained from $250 \mathrm{~kg} / \mathrm{ha}$, NPK (T1) and control (T7), respectively were not significantly different but were significantly (P $\leq 0.05)$ higher than $2.15 \mathrm{~cm}$ obtained from $2 \mathrm{t} /$ ha cattle dung (T2).

At 10 WAT, application of $3 \mathrm{t} / \mathrm{ha}$ cattle dung+300 kg/ha NPK (T4) gave the best stem girth of $3.53 \mathrm{~cm}$ which was not significantly $(\mathrm{P} \leq 0.05)$ different from 3.50 and $3.50 \mathrm{~cm}$ obtained from $4 \mathrm{t} / \mathrm{ha}$ cattle dung $+350 \mathrm{~kg} / \mathrm{ha} \mathrm{NPK}$ (T5) and $5 \mathrm{t} / \mathrm{ha}$ cattle dung+400 kg/ha NPK (T6), respectively. Also, application of $2 \mathrm{t} / \mathrm{ha}$ cattle dung+250 kg/ha NPK (T3) gave $3.15 \mathrm{~cm}$ stem girth which was significantly $(\mathrm{P} \leq 0.05)$ higher than $2.60,2.45$ and $2.48 \mathrm{~cm}$ obtained from $250 \mathrm{~kg} / \mathrm{ha} \mathrm{NPK}$ (T1), $2 \mathrm{t} /$ ha cattle dung (T2) and control (T7), respectively. On the other hand, application of $250 \mathrm{~kg} / \mathrm{ha}$ NPK (T1) gave $2.60 \mathrm{~cm}$ stem girth which was significantly $(\mathrm{P} \leq 0.05)$ higher than 2.45 and $2.48 \mathrm{~cm}$ obtained from $2 \mathrm{t} /$ ha cattle dung $(\mathrm{T} 2)$ and control (T7), respectively. However, control (T7) and 2 t/ha cattle dung (T2) with values of 2.48 and $2.45 \mathrm{~cm}$ stem girth, respectively were not significantly $(\mathrm{P} \leq 0.05)$ different from each other.

At 12 WAT, application of 3 t/ha cattle dung+300 kg/ha NPK (T4) gave the best stem girth of $3.53 \mathrm{~cm}$ which was not significantly $(\mathrm{P} \leq 0.05)$ different from 3.50 and $3.50 \mathrm{~cm}$ obtained from $4 \mathrm{t} / \mathrm{ha}$ cattle dung+350 $\mathrm{kg} / \mathrm{ha}$ NPK (T5) and $5 \mathrm{t} / \mathrm{ha}$ cattle dung+400 kg/ha NPK (T6), respectively. Also, application of $2 \mathrm{t} / \mathrm{ha}$ cattle dung+250 kg/ha NPK (T3) gave $3.15 \mathrm{~cm}$ stem girth which was significantly $(\mathrm{P} \leq 0.05)$ higher than $2.60,2.45$ and $2.48 \mathrm{~cm}$ obtained from $250 \mathrm{~kg} / \mathrm{ha} \mathrm{NPK}$ (T1), 2 t/ha cattle dung (T2) and control (T7), respectively. On the other hand, application of $250 \mathrm{~kg} / \mathrm{ha}$ NPK (T1) gave $2.60 \mathrm{~cm}$ stem girth which was significantly $(\mathrm{P} \leq 0.05)$ higher than 2.45 and $2.48 \mathrm{~cm}$ obtained from $2 \mathrm{t} /$ ha cattle dung (T2) and control (T7), respectively. The control (T7) and $2 \mathrm{t} /$ ha cattle dung (T2) had no significant $(\mathrm{P} \leq 0.05)$ difference.

Table-8: Effect of organic and inorganic fertilizer on stem girth $(\mathrm{cm})$ of fluted pumpkin during the dry season of 2015

\begin{tabular}{|l|l|l|l|l|l|l|}
\hline Treatments & 2WAT & 4WAT & 6WAT & 8WAT & 10WAT & 12WAT(cm) \\
\hline T1 & $1.08^{\mathrm{a}}$ & $1.50^{\mathrm{b}}$ & $1.75^{\mathrm{c}}$ & $2.35^{\mathrm{c}}$ & $2.60^{\mathrm{c}}$ & $2.60^{\mathrm{c}}$ \\
\hline T2 & $1.10^{\mathrm{a}}$ & $1.55^{\mathrm{b}}$ & $1.73^{\mathrm{c}}$ & $2.15^{\mathrm{d}}$ & $2.45^{\mathrm{d}}$ & $2.45^{\mathrm{d}}$ \\
\hline T3 & $1.15^{\mathrm{a}}$ & $1.65^{\mathrm{a}}$ & $2.08^{\mathrm{b}}$ & $2.85^{\mathrm{b}}$ & $3.15^{\mathrm{b}}$ & $3.15^{\mathrm{b}}$ \\
\hline T4 & $1.20^{\mathrm{a}}$ & $1.70^{\mathrm{a}}$ & $2.40^{\mathrm{a}}$ & $3.23^{\mathrm{a}}$ & $3.53^{\mathrm{a}}$ & $3.53^{\mathrm{a}}$ \\
\hline T5 & $1.10^{\mathrm{a}}$ & $1.55^{\mathrm{b}}$ & $2.43^{\mathrm{a}}$ & $3.20^{\mathrm{a}}$ & $3.50^{\mathrm{a}}$ & $3.50^{\mathrm{a}}$ \\
\hline T6 & $1.10^{\mathrm{a}}$ & $1.60^{\mathrm{a}}$ & $2.08^{\mathrm{b}}$ & $3.05^{\mathrm{a}, \mathrm{b}}$ & $3.35^{\mathrm{a}, \mathrm{b}}$ & $3.35^{\mathrm{a}, \mathrm{b}}$ \\
\hline T7 (control) & $1.00^{\mathrm{b}}$ & $1.48^{\mathrm{b}}$ & $1.73^{\mathrm{c}}$ & $2.23^{\mathrm{c}}$ & $2.48^{\mathrm{d}}$ & $2.48^{\mathrm{d}}$ \\
\hline Mean & 1.10 & 1.58 & 2.03 & 2.72 & 3.01 & 3.01 \\
\hline LSD(P $\leq 0.05)$ & 0.16 & 0.16 & 0.18 & 0.18 & 0.18 & 0.18 \\
\hline
\end{tabular}

Note: Means followed by same letter(s) in a column are not significantly different $(\mathrm{P} \leq 0.05)$.

$\mathrm{T} 1=250 \mathrm{~kg} / \mathrm{ha}$ NPK, T2 $=2 \mathrm{t} / \mathrm{ha}$ cattle dung, T3 = $2 \mathrm{t} / \mathrm{ha}$ cow dung $+250 \mathrm{~kg} / \mathrm{ha} \mathrm{NPK}, \mathrm{T} 4=3 \mathrm{t} / \mathrm{ha}$ cattle dung +300 $\mathrm{kg} / \mathrm{ha}$ NPK, T5 = 4 t/ha cattle dung $+350 \mathrm{~kg} / \mathrm{ha} \mathrm{NPK,} \mathrm{T6} \mathrm{=} 5$ t/ha cattle dung $+400 \mathrm{~kg} / \mathrm{ha} \mathrm{NPK}, \mathrm{T} 7=$ control, LSD Least Significant Difference 
Effects of organic and inorganic fertilizers on internode length of fluted pumpkin during the dry season of 2015

From Table-9, at 2 WAT, application of 2 t/ha cattle dung+250 kg/ha NPK (T3) and 5 t/ha cattle dung+400 $\mathrm{kg} / \mathrm{ha}$ NPK (T6) gave the highest internode length of $3.60 \mathrm{~cm}$ but was not significantly $(\mathrm{P} \leq 0.05)$ different from $3 \mathrm{t} / \mathrm{ha}$ cattle dung+300 kg/ha NPK (T4) and 4 t/ha cattle dung+350 kg/ha NPK (T5) that gave $3.50 \mathrm{~cm}$. However, application of $250 \mathrm{~kg} / \mathrm{ha}$ NPK (T1) which gave $3.13 \mathrm{~cm}$ internode length was not significantly $(\mathrm{P} \leq 0.05)$ different from 3.05 and $3.0 \mathrm{~cm}$ obtained from 2 t/ha cattle dung (T2) and control (T7), respectively.

At 4 WAT, application of 2 t/ha cattle dung+250 kg/ha NPK (T3) and 5 t/ha cattle dung+400 kg/ha NPK (T6) gave the highest internode length of $3.70 \mathrm{~cm}$ which was not significantly $(\mathrm{P} \leq 0.05)$ different from $3.65 \mathrm{~cm}$ obtained from the application of $3 \mathrm{t} / \mathrm{ha}$ cattle dung+300 kg/ha NPK (T4) and $4 \mathrm{t} / \mathrm{ha}$ cattle dung+350 kg/ha NPK (T5), respectively but were significantly $(\mathrm{P} \leq 0.05)$ higher than other treatments and control. However, application of $250 \mathrm{~kg} / \mathrm{ha}$ NPK (T1) which gave $3.18 \mathrm{~cm}$ internode length was not significantly $(\mathrm{P} \leq 0.05)$ different from $3.10 \mathrm{~cm}$ obtained from $2 \mathrm{t} / \mathrm{ha}$ cattle dung (T2) and control (T7), respectively.

At 6 WAT, application of 2 t/ha cattle dung+250 kg/ha NPK (T3) gave the highest internode length of $4.08 \mathrm{~cm}$ which was not significantly $(\mathrm{P} \leq 0.05)$ different from $4.07,4.00$ and $4.03 \mathrm{~cm}$ obtained from the application of $5 \mathrm{t} / \mathrm{ha}$ cattle dung+400 kg/ha NPK (T6), 3 t/ha cattle dung+300 kg/ha NPK (T4) and 4 t/ha cattle dung+350 kg/ha NPK (T5), respectively but were significantly $(\mathrm{P} \leq 0.05)$ higher than other treatments and control. However, application of $250 \mathrm{~kg} / \mathrm{ha}$ NPK (T1) gave $3.43 \mathrm{~cm}$ internode length was not significantly $(\mathrm{P} \leq 0.05)$ different from $3.25 \mathrm{~cm}$ obtained from $2 \mathrm{t} / \mathrm{ha}$ cattle dung (T2) and control (T7), respectively.

At 8 WAT, application of 5 t/ha cattle dung+400 kg/ha NPK (T6) gave the highest internode length of $5.50 \mathrm{~cm}$ which was not significant $(\mathrm{P} \leq 0.05)$ different from $5.30 \mathrm{~cm}$ obtained from the application of $3 \mathrm{t} / \mathrm{ha}$ cattle dung $+300 \mathrm{~kg} / \mathrm{ha}$ NPK (T4) but was significantly $(\mathrm{P} \leq 0.05)$ higher than other treatments and control. However, application of $250 \mathrm{~kg} / \mathrm{ha}$ NPK (T1) gave $5.20 \mathrm{~cm}$ internode length which was not significantly $(\mathrm{P} \leq 0.05)$ different from $5.17,5.10,5.03$ and 4.67 $\mathrm{cm}$ internode length obtained from the application of $4 \mathrm{t} / \mathrm{ha}$ cattle dung+350 kg/ha NPK (T5), $2 \mathrm{t} / \mathrm{ha}$ cattle dung+250 $\mathrm{kg} / \mathrm{ha}$ NPK (T3) $2 \mathrm{t} / \mathrm{ha}$ cattle dung (T2) and control (T7), respectively.

At 10 WAT, application of $5 \mathrm{t} / \mathrm{ha}$ cattle dung+400 kg/ha NPK (T6) gave the highest internode length of $5.57 \mathrm{~cm}$ which was not significant $(\mathrm{P} \leq 0.05)$ different from $5.37 \mathrm{~cm}$ obtained from the application of $3 \mathrm{t} / \mathrm{ha}$ cattle dung $+300 \mathrm{~kg} / \mathrm{ha}$ NPK (T4) but was significantly $(\mathrm{P} \leq 0.05)$ higher than other treatments and control. However, application of $250 \mathrm{~kg} / \mathrm{ha}$ NPK (T1) gave $5.23 \mathrm{~cm}$ internode length which was not significantly $(\mathrm{P} \leq 0.05)$ different from 5.20, 5.20, 5.05 and 4.68 $\mathrm{cm}$ internode length obtained from the application of $4 \mathrm{t} / \mathrm{ha}$ cattle dung+350 kg/ha NPK (T5), $2 \mathrm{t} / \mathrm{ha}$ cattle dung+250 $\mathrm{kg} / \mathrm{ha}$ NPK (T3) $2 \mathrm{t} / \mathrm{ha}$ cattle dung (T2) and control (T7), respectively.

At 12 WAT, application of 5 t/ha cattle dung+400 kg/ha NPK (T6) gave the highest internode length of $5.58 \mathrm{~cm}$ which was not significantly $(\mathrm{P} \leq 0.05)$ different from $5.38 \mathrm{~cm}$ obtained from the application of $3 \mathrm{t} / \mathrm{ha}$ cattle dung+300 $\mathrm{kg} /$ ha NPK (T4) but was significantly $(\mathrm{P} \leq 0.05)$ higher than other treatments and control. However, application of 250 $\mathrm{kg} /$ ha NPK (T1) gave $5.23 \mathrm{~cm}$ internode length but was not significantly $(\mathrm{P} \leq 0.05)$ different from $5.20,5.20,5.05$ and $4.68 \mathrm{~cm}$ internode length obtained from the application of $4 \mathrm{t} / \mathrm{ha}$ cattle dung+350 kg/ha NPK (T5), $2 \mathrm{t} / \mathrm{ha}$ cattle dung+250 $\mathrm{kg} / \mathrm{ha}$ NPK (T3), 2 t/ha cattle dung (T2) and control (T7) respectively.

Table-9: Effect of organic and inorganic fertilizers on internode length $(\mathrm{cm})$ per stand of fluted pumpkin during the dry season of 2015

\begin{tabular}{|l|l|l|l|l|l|l|}
\hline Treatments & 2WAT & 4WAT & 6WAT & 8WAT & 10WAT & 12WAT(cm) \\
\hline T1 & $3.13^{\mathrm{b}}$ & $3.18^{\mathrm{b}}$ & $3.43^{\mathrm{b}}$ & $5.20^{\mathrm{b}}$ & $5.23^{\mathrm{b}}$ & $5.23^{\mathrm{b}}$ \\
\hline T2 & $3.05^{\mathrm{b}}$ & $3.10^{\mathrm{b}}$ & $3.25^{\mathrm{b}}$ & $5.03^{\mathrm{b}}$ & $5.05^{\mathrm{b}}$ & $5.05^{\mathrm{b}}$ \\
\hline T3 & $3.60^{\mathrm{a}}$ & $3.70^{\mathrm{a}}$ & $4.08^{\mathrm{a}}$ & $5.10^{\mathrm{b}}$ & $5.20^{\mathrm{b}}$ & $5.20^{\mathrm{b}}$ \\
\hline T4 & $3.55^{\mathrm{a}}$ & $3.65^{\mathrm{a}}$ & $4.00^{\mathrm{a}}$ & $5.30^{\mathrm{a}}$ & $5.37^{\mathrm{a}}$ & $5.38^{\mathrm{a}}$ \\
\hline T5 & $3.55^{\mathrm{a}}$ & $3.65^{\mathrm{a}}$ & $4.03^{\mathrm{a}}$ & $5.17^{\mathrm{b}}$ & $5.20^{\mathrm{b}}$ & $5.20^{\mathrm{b}}$ \\
\hline T6 & $3.60^{\mathrm{a}}$ & $3.70^{\mathrm{a}}$ & $4.07^{\mathrm{a}}$ & $5.50^{\mathrm{a}}$ & $5.57^{\mathrm{a}}$ & $5.58^{\mathrm{a}}$ \\
\hline T7 (control) & $3.00^{\mathrm{b}}$ & $3.10^{\mathrm{b}}$ & $3.25^{\mathrm{b}}$ & $4.67^{\mathrm{c}}$ & $4.68^{\mathrm{c}}$ & $4.68^{\mathrm{c}}$ \\
\hline Mean & 3.35 & 3.44 & 3.72 & 5.13 & 5.18 & 5.18 \\
\hline LSD(P $\leq 0.05)$ & 0.32 & 0.32 & 0.27 & 0.28 & 0.27 & 0.27 \\
\hline
\end{tabular}

Note: Means followed by same letter(s) in a column are not significantly different $(\mathrm{P} \leq 0.05)$.

$\mathrm{T} 1=250 \mathrm{~kg} / \mathrm{ha} \mathrm{NPK}, \mathrm{T} 2=2 \mathrm{t} / \mathrm{ha}$ cattle dung, T3 = $2 \mathrm{t} / \mathrm{ha}$ cow dung $+250 \mathrm{~kg} / \mathrm{ha} \mathrm{NPK}, \mathrm{T} 4=3 \mathrm{t} / \mathrm{ha}$ cattle dung +300 $\mathrm{kg} / \mathrm{ha} \mathrm{NPK}, \mathrm{T} 5=4 \mathrm{t} / \mathrm{ha}$ cattle dung $+350 \mathrm{~kg} / \mathrm{ha} \mathrm{NPK}, \mathrm{T} 6=5 \mathrm{t} / \mathrm{ha}$ cattle dung $+400 \mathrm{~kg} / \mathrm{ha} \mathrm{NPK}, \mathrm{T} 7=\mathrm{control}, \mathrm{LSD}-$ Least Significant Difference 


\section{DisCUSSIONS}

\section{Precropping Soil Physical and Chemical Analyses}

The available $\mathrm{P}$ was below the critical value of $15 \mathrm{mg} / \mathrm{kg}$ in soil [27]. Since $\mathrm{pH}$ of most agricultural soils in Nigeria has been reported to be 4.0 - 6.5 [28]. The precropping $\mathrm{pH}$ of 5.1 may be suitable for nutrient availability for the fluted pumpkin. EC value was moderate $(0.25 \mathrm{dS} / \mathrm{m})$ which shows that the soil is not saline [29]. Available P 10.71 $\mathrm{mg} / \mathrm{kg}$ is good for vegetable crop production. From the recommendations of [9], the soil was low in total N and OC. The Organic carbon content was $0.34 \mathrm{~g} / \mathrm{kg}$ and was below the critical value of $3.4 \mathrm{~g} / \mathrm{kg}$ [30]. Total $\mathrm{N}$ was $0.02 \mathrm{~g} / \mathrm{kg}$ but was below the critical value of $0.15 \mathrm{~g} / \mathrm{kg}$ [31]. The values reflected the amount of organic matter in soil considering the fact that these soils are below the critical value for optimum crop production. The low amounts of organic matter and total $\mathrm{N}$ contents could lead to low water retention capacity of the soil, yellowing of leaves and retarded plant growth. The low contents of total $\mathrm{N}$ and $\mathrm{OC}$ could be attributed to the effects of intensive and continuous cultivation that may aggravate organic matter oxidation and their consequent leaching/erosion. Saik, $\mathrm{H}$ et al., \& Negassa, W et al., reported that the continuous cultivation of land results in the reduction of $\mathrm{OC}$ and total $\mathrm{N}$ contents $[32,33]$. In addition, the low $\mathrm{N}$ content may also be attributed to sandy nature of the soil which could aid rapid leaching of $\mathrm{N}$.

The soil was high in exchangeable $\mathrm{Na}, \mathrm{Mg}, \mathrm{Ca}$ and $\mathrm{K}$. Exchangeable $\mathrm{Mg}$ content was $2.63 \%$ was above the critical value of $0.4 \%$ [34]. The Ca content was $4.04 \%$ and above the critical value of $2.0 \%$ [34]. Potassium was $2.17 \%$ and was above the critical value of $2.0 \%$ [34]. High amounts of $\mathrm{Mg}$, $\mathrm{Ca}$, and $\mathrm{K}$ are expected to help in the stabilization of all membranes and cell wall, interaction among plant hormones and in photosynthesis as $\mathrm{Mg}$ serves as a component of chlorophyll. The results of the exchangeable acidity was $1.27 \%$. This implies that exchangeable acidity value was less than $4 \%$ in the soil. This value reflects the moderate acidity values of the soils. The ECEC was $11.28 \%$. It had been suggested that the ECEC of a soil is a permanent characteristic and directly related to the soil texture [35]. The higher the clay content of any soil, the higher the ECEC of a soil. In general, the ECEC of most soils increase with an increase in soil $\mathrm{pH}[35]$. The particle size analysis revealed that the soil was sandy loam.

\section{Effects of cattle dung and NPK fertilizer rates on soil chemical properties planted to fluted pumpkin}

Significant differences in soil chemical properties such as soil $\mathrm{pH}$, OC, total $\mathrm{N}$, available $\mathrm{P}$, electrical conductivity, exchangeable, $\mathrm{K}, \mathrm{Ca}, \mathrm{Mg}$ and $\mathrm{Na}$ were evident. The combined applications of cattle dung and NPK fertilizer improved soil $\mathrm{pH}, \mathrm{P}, \mathrm{OC}, \mathrm{N}$, and $\mathrm{K}$ compared to application of either cattle dung or NPK fertilizer alone. The increases in soil OC, N, K, and P observed after harvest in soils treated with combined use of organic and inorganic fertilizers might be as a result of the slow rate in which the nutrients in the cattle dung were released into the soil. The increases in soil OC, N, K, and P observed after harvest in soils treated with combined use of organic and inorganic fertilizers might be as a result of the slow rate in which the nutrients in the cattle dung were released into the soil. Akinyele, B. O et al., [36] posited that organic fertilizers showed greater capacity than inorganic fertilizers in retaining nutrients in forms that can easily be taken by plants over a longer period.

Vivekananda, $\mathrm{M}$ et al., [37], reported that the buildup of $\mathrm{P}$ through application of cattle dung was as a result of the mineralization of organic phosphate by the soil microorganisms and the production of organic acids, which make soil $\mathrm{P}$ more available. Combined application of cow dung and NPK increased SOC contents. This increase with the application of cattle dung could be attributed to the potential of organic waste to enrich soil organic matter. This increase might be due to the high rates of application of cattle dung with high OC contents and root residue decomposition of plants that had grown luxuriantly with such high rate of organic manure and medium $\mathrm{N}$ fertilizers. These results are consistent with those of [38] who reported that the application of organic manure in combination with inorganic fertilizers exerted greater influence and linearly increased soil OC levels.

The soil had very low content of $\mathrm{OC}$, and total $\mathrm{N}$ which are indicators of low inherent fertility status, which underscore the need for improved soil management techniques. The result showed that combined use of cattle dung and NPK reduced $\mathrm{N}$ loss from the soil thereby increasing available $\mathrm{N}$ in the soil. This is in agreement with the observations of [39] as cited in [40] that joint application of organic and inorganic fertilizers reduced, among other things, losses of nutrients by leaching. Increase in ECEC of the soil by addition of cattle dung may be attributed to the better buffer capacity of the soil as a result of the high organic matter content of the manure added [41].

\section{Effects of nutrient sources and rates on some selected soil physical properties.}

Results from this study showed that nutrient sources had no significant effect $(\mathrm{p}=0.05)$ on bulk density, gravimetric water content, porosity, and volumetric water content in the experiment. The results from this study is in contrast to previous studies $[42,43]$ who observed that organic manure contributed to improvement of soil physical properties such as soil bulk density, porosity, soil water infiltration and water holding capacity. 


\section{Effects of cattle dung and NPK fertilizer on fluted pumpkin growth parameters}

From the results obtained, it was observed that combined applications of cattle dung and NPK fertilizer increased fluted pumpkin numbers of leaves, branches, stem girth and internode length. The findings are similar to those of [44] who reported better vegetative growth in amaranth from the effect of combined application of organic and inorganic nutrient sources. Increase in the vegetative growth of fluted pumpkin could be attributed to increase in $\mathrm{N}$ and $\mathrm{P}$ uptake by fluted pumpkin. $\mathrm{P}$ and $\mathrm{N}$ increase cell division in all the important growth parameters, and enhanced $\mathrm{N}$ nutrient increases the photosynthetic capacity of the crop, thus resulting in more assimilates being partitioned to the various plant parts which consequently influenced the growth of the crop [45]. On the other hand, the significant effects obtained with the application of both cattle dung and NPK 15:15:15 fertilizer may be attributed to the initial low soil fertility of the experimental site. Tisdale, S. A et al., Ndaeyo, N. U et al., Makinde, E. A et al., \& Uko, A. E et al., noted that crop response to fertilizer application is affected by nutrient reserve in the soil. According to them, crops respond more to fertilizer application in soils with very low nutrient contents than soils with high nutrient reserves [46-49].

It was also observed that number of leaves and branches of pumpkin plants increased with increased application of all nutrient sources (organic, inorganic and a combination of both) with combination of organic and inorganic fertilizer excelling above the other nutrient sources. The inorganic nutrient source ranked second in terms of number of leaves, a trend that can be attributed to nutrients being readily available and better utilization of nutrients at higher NPK levels. Akanbi, W. B et al., [5], reported that organic source improved cell activity, enhanced cell multiplication and enlargement of fluted pumpkin. Grubben, G. J. H et al., [50] observed that organic manure contributed significantly to the number of vines, vine length and number of leaves in vegetables depending on the rate of application. Organic manure is known to be capable of activating many species of microorganisms which release phyto hormones that stimulate nutrient absorption and plant growth [48]. Organic fertilizer apart from releasing nutrient elements to the soil has also been shown to improve other soil chemical and physical properties which enhance crop growth and development [51-53, 49]. This may be responsible for the better performances recorded in plants that had combinations of cattle dung and inorganic fertilizer than crops that received either sole cattle dung or sole inorganic fertilizer treatments. This agrees with the results obtained in other crops including amaranth [54, 51, 55, 47, 49].

Also, combined application of cattle dung and mineral fertilizer generally increased number of branches and stem girth compared to sole organic or sole inorganic which are similar to the findings of [44]. The inorganic fraction of the combination releases its nutrients early enough for plant use while the organic portion could stimulate microbial activities and prevent loss of nutrients. This is in line with the observations of [56, 57]. The increase in the number of branches led to increase in the number of leaves which in turn allowed for better photosynthetic activity of plants. Plant diameter or girth would have positive implication on lodging, particularly during fruiting; the thicker the stem, the less likely the plant would lodge as a result of fruit carriage or other lodge-inducing factors such as wind. Ogbonna, P. E [51], stated that for healthy stem development, plants require adequate amounts of potassium and phosphorus. These nutrients are also available in cattle dung and are released slowly throughout the growing season.

\section{SumMary AND CONCLUSIONS}

Combined use of cattle dung and NPK fertilizer was superior to sole application of organic fertilizer (cattle dung) or inorganic fertilizer (NPK 15:15:15) in improving soil chemical properties, nutrient uptake and growth of fluted pumpkin. Application of $5 \mathrm{t} / \mathrm{h}$ cattle dung and $400 \mathrm{~kg} / \mathrm{ha}$ NPK fertilizer improved soil physicochemical properties, nutrient uptake and growth of fluted pumpkin in the experiment. Application of $5 \mathrm{t} / \mathrm{ha}$ cattle dung and $400 \mathrm{~kg} / \mathrm{ha}$ NPK fertilizer (T6) also improved soil physicochemical properties, nutrient uptake and growth of fluted pumpkin but 4 t/ha cattle dung and $350 \mathrm{~kg} / \mathrm{ha}$ NPK (T5) recorded the highest stem girth and number of branches from 8 to 12 WAT. Also, 3 t/ha cattle dung and $300 \mathrm{~kg} / \mathrm{ha}$ NPK (T4) recorded the highest internode length from 4 to 12 WAT. The control pot had the lowest values for all the growth parameters

From the results of this study, it is suggested that for the cultivation of fluted pumpkin in Anyigba, Kogi State, a combination of $5 \mathrm{t} / \mathrm{ha}$ cattle dung and $400 \mathrm{~kg} / \mathrm{ha}$ NPK 15:15:15 fertilizer may be used. Considering the affordability of inorganic fertilizers and its effect on the environment, farmers who cannot afford $400 \mathrm{~kg} / \mathrm{ha}$ NPK 15:15:15 fertilizer can apply $250 \mathrm{~kg} / \mathrm{ha} \mathrm{NPK}+5 \mathrm{t} / \mathrm{ha}$ cattle dung for fluted pumpkin production.

\section{REFERENCES}

1. Zhu, Z. L. (2000). Farmland in nitrogen loss and countermeasures. Journal of Soil and Environment, 9(1), 1-6.

2. Suge, J. K., Omunyin, M. E., \& Omami, E. N. (2011). Effect of organic and inorganic sources of fertilizer on growth, yield and fruit quality of eggplant (Solanum melongena L). Archives of Applied Science Research, 3(6), 470-479. 
3. Amhakhian, S. O., Oyewole, C. I., \& Isitekhale, H. H. (2010). Effects of different levels of Phosphorus on the growth and yield of maize (Zea mays L.) in Ofere (Basement complex) soils Kogi State, North Central ecological zone, Nigeria. Continental Journal of Agricultural Science, 4, 20-28.

4. Khan, M. S., Shil, N. C., \& Noor, S. (2008). Integrated nutrient management for sustainable yield of major vegetable crops in Bangladesh. Bangladesh J Agric Environ, 4, 81-94.

5. Akanbi, W. B., Adeboye, C. O., Togun, A. O., Ogunrinde, J. O., \& Adeyeye, S. A. (2007). Growth herbage and seed yield and quality of Telfeina occidentalis as influenced by cassava peal compost and mineral fertilizer. World Journal of Agricultural Science, 3(4), 308516.

6. Axtell, B. L., \& Fairman, R. M. (1992). Minor oil crops FAO agricultural services bulletin No. 94.

7. Okoli, B. E., \& Mgbeogu, C. M. (1983). Fluted pumpkin, Telfairia occidentalis: West African vegetable crop. Economic Botany, 37(2), 145-149.

8. Horsfall, J. M., \& Spiff, I. A. (2005). Equilibrium sorption study of Al, Co3+ and Ag2+ in aqueous solution of fluted pumpkin (Telfairia occidentalis Hookf) waste biomass. Acta Chim Slov, 52: 174-181.

9. Udoh, J., Ndon, B. A., Asuquo, P. E., \& Ndaeyo, N. U. (2005). Crop Production Techniques for the Tropics Concept Publications Limited. Munshin, Lagos Nigeria, 101-106.

10. Ossom, E. M., Igbokwe, J. R., \& Rhykerd, C. L. (1996, January). Effects of Mixed Fertilizer Levels and Harvest Intervals On The Yield And Mineral Concentration Of The Fluted Pumpkin, Telfairia Occidentals Hook. In Proceedings of the Indiana Academy of Science, 105(3-4), 169-176.

11. Akoroda, M. O. (1990). Ethnobotany ofTelfairia occidentalis (cucurbitaceae) among Igbos of Nigeria. Economic botany, 44(1), 29-39.

12. Sharma, A. R., \& Mittra, B. N. (1991). Effect of different rates of application of organic and nitrogen fertilizers in a rice-based cropping system. The Journal of Agricultural Science, 117(3), 313-318.

13. Abou El-Magd, M. M., Hoda, M. A., \& Fawzy, Z. F. (2005). Relationships, growth, yield of broccoli with increasing N, P or K ratio in a mixture of NPK fertilizers. Annals Agricultural Science Moshtohor, 43(2), $791-805$.

14. Awodun, M. A. (2007). Effect of poultry manure on the growth, yield and nutrient content of fluted pumpkin (Telfaria occidentalis Hook F). Asian J. Agric. Res, 1(2), 67-73.

15. Adeniyan, O. N., \& Ojeniyi, S. O. (2003). Comparative effectiveness of different levels of poultry manure with NPK fertilizer on residual soil fertility, nutrient uptake and yield of maize. Moor Journal of Agricultural Research, 4(2), 191-197.

16. Adekiya. A. O., \& Agbede, T. M. (2009). Growth and yield of tomato (Lycopersicon esculentum Mill) as influenced by poultry manure and NPK fertilizer. Emir. Journal Food Agric. 21(1):10-20

17. Blake, G. R., \& Hartge, K. H. (1986). Bulk density in methods of Soil Analysis, Part I. Physical and mineralogical methods. A Klute (ed). American soil Agronomy Madison, WI, U.S.A. 365-375.

18. Ibitoye, A. A. (2006). Hand Book for Technologist. G.A Ogunleye printing Enterprise, Akure, Ondo State, 82.

19. Bouyoucos, G. J. (1951). A recalibration of the hydrometer method for making mechanical analysis of soils 1. Agronomy journal, 43(9), 434-438.

20. Gee, G. W., \& Bauder, D. (1985). Particle size analysis. In: Dane, J.H. and Topp, G.C. (Eds). Methods of soil analysis. Part 4 Physical methods. Soil Science Society Am Book Series 5. ASA and SSSA, Madison, W1, 255-293.

21. Bremner, J. M. (1982). Total nitrogen. Methods of soil analysis. Am. Soc. Agron. Mongrn 10, 2, 594-624.

22. Bray, R. H., \& Kurtz, L. T. (1945). Determination of total, organic, and available forms of phosphorus in soils. Soil science, 59(1), 39-46.

23. Chen, Z. S. (1998). Selecting the indicators to evaluated the soil quality of Taiwan soils and approaching the national level of sustainable soil management. In Proceedings of International Seminar on Soil management for Sustainable Agriculture in the Tropics. Dec. 14-19, 1998, Taichung, Taiwan, ROC.

24. Walkley, A., \& Black, I. A. (1934). An examination of the Degtjareff method for determining soil organic matter, and a proposed modification of the chromic acid titration method. Soil science, 37(1), 29-38.

25. Thomas, G. W. (1982). Exchangeable cation. In Page, A. L., Moller, R. H., \& Keeney, D. R., (eds) method of soil analysis part 2. Second Edition. America Society of Agronomy, Madison, 157-164.

26. Maclean, E. O. (1982). Soil pH and lime requirements in Page. A.L. (Ed) methods of Soil Analysis part 2 chemical and microbiological properties second edition, Agronomy Series No.9 America Society of Agronomy, Soil Science Society America Madison, Wisconsin, USA.

27. Enwezor, W. O., Udo, E. J., \& Sobulo, R. A. (1981). Fertility status and productivity of acid sand. In acid sand of southern Nigeria Soil Science Society of Nigeria. Special publication, 1: 56-73.

28. Hartly, C. W. S. (1988). The oil palm (Elaeis guinensis jacq) $2^{\text {nd }}$ edition, Longman, London and New York, pages: 824.

29. USDA-Soil Classification Series (SCS). (1974). Soil Quality Resource Concerns:pH and Electrical conductivity.

30. Kemper, W. D., \& Koch, E. J. (1986). Aggregating stability of soil from Western United States and Canada. Colorado. Agric Exp Stn Bull, 1355, 1-52.

31. Sobulo, R. A., \& Osiname, A. (1981). Soil and Fertilizer use in Southwestern Nigeria, 'Research Bulletin 11, IART, Ibadan, Nigeria. 
32. Saikh, H., Varadachari, C., \& Ghosh, K. (1998). Changes in carbon, nitrogen and phosphorus levels due to deforestation and cultivation: a case study in Simlipal National Park, India. Plant and Soil, 198(2), 137-145.

33. Negassa, W., \& Gebrekidan, H. (2003). Forms of phosphorus and status of available micronutrients under different land-use systems of Alfisols in Bako area of Ethiopia. Ethiopian Journal of Natural Resources, 5(1), 17-37.

34. Anon. (1990). Literature review in Soil Fertility investigation in (in five volumes) FMANR Lagos, 25-30.

35. FAO (Food and Agricultural Organization). (2000). Fertilizers and their use. A pocket guide for extension officers. FAO, Rome.

36. Akinyele, B. O., Aiyelari, O. P., \& Adeleke, O. A. (2012). The comparative effects of organic manuresand inorganic fertilizer on the growth and yield of Celosia argentea. The International Journal of Science in Society 3(2): 23-33.

37. Vivekanandan, M., \& Fixen, P. E. (1990). Effect of large manure applications on soil P intensity. Communications in soil science and plant analysis, 21(3-4), 287-297.

38. Ding, X., Han, X., Liang, Y., Qiao, Y., Li, L., \& Li, N. (2012). Changes in soil organic carbon pools after 10 years of continuous manuring combined with chemical fertilizer in a Mollisol in China. Soil and Tillage Research, 122, 36-41.

39. Reijntjes, C., Haveskort, B., \& Waterbayer, A. (1993). Farming for future. An introduction to low external inputs and sustainable Agriculture. The McMillanPress, Leuden; ILEIA. Netherlands, 250.

40. Okigbo, B. N. (2000). Enhancing the development of research in Agricultural root cropsand natural science. Paper presented at the National Workshop on Sustainable Agriculture, Food Self Sufficiency, Poverty Alleviation and Rural Development held from 22 - 26 May, 2000. NRCRI Umudike, Nigeria.

41. Meelu, O. P., \& Gill, H. S. (2001). Studies on the substitution of inorganic fertilizer. Journal of Science in Society 3(2): 23-33.

42. Mullins, G. L. (2002). Poultry litter as a fertilizer and Soil Amendment. Agriculture and Natural resource Virginia Tech. organic Research. http/www.organic.research.com

43. Weber, J., Karczewska, A., Drozd, J., Licznar, M., Licznar, S., Jamroz, E., \& Kocowicz, A. (2007). Agricultural and ecological aspects of a sandy soil as affected by the application of municipal solid waste composts. Soil Biology and Biochemistry, 39(6), 1294-1302.

44. Akande, M. O., Oluwatoyinbo, F. I., Makinde, E. A., Adepoju, A. S., \& Adepoju, I. S. (2010). Response of okra to organic and inorganic fertilization. Nature and Science, 8 (11):262-266

45. Kling, J. G., \& Edmeades, G. (1997). Morphology and growth of maize. IITA/CIMMYT Resource Guide 9. Training Programmes. IITA Ibadan, Nigeria, 19-20.

46. Tisdale, S. A., \& Nelson, W. L. (1975). Soil Fertility and fertilizers. Macmillan Publishing Company Inc. (3rd ed.) N. Y.

47. Ndaeyo, N. U., Ukpong, E. S., \& John, N. M. (2005). Performances of okra as affected by organic and inorganic fertilizers on an utisol. In Proceedings of the 39th Conference of the Agricultural Society of Nigeria, October (pp. 9 13).

48. Makinde, E. A., Ayoola, O. T., \& Akande, M. O. (2007). Effects of organic-mineral fertilizer application on the growth and yield of "egusi" melon (Citrullus vulgaris L.). Australian Journal of Basic and applied sciences, 1(1), 15-19.

49. Uko AE, Udo IA, Shiyam JO. Optimizing poultry manure rates for two okra (Abelmoschus esculentus) varieties in a warm wet climate. Journal of Agriculture, Biotechnology and Ecology. 2009;2(3):273-85.

50. Denton, O. A., Schippers, R. R., \& Oyen, L. P. A. (2004). Plant resources of tropical Africa, 2: Vegetables. Fondation PROTA, Wageningen, Pays-Bas/CTA, Wageningen Pays-Bas, 522-526.

51. Ogbonna, P. E. (2008). Effect of combined application of organic and inorganic fertilizers on fruit yield of egg plant (Solanum melongena). Pro. In 42nd Annual conf. Agricultural Society of Nigeria (ASN) October, 19(23), 236-250.

52. Dauda, S. N., Ajayi, F. A., \& Ndor, E. (2008). Growth and yield of water melon (Citrullus lanatus) as affected by poultry manure application. J. Agric. Soc. Sci, 4(3), 121-124.

53. Stevenson, F. S., \& Ardakani, M. S. (1972). Organic matter reactions involving micronutrients in soil, Madison, Soil Science Society of America. 79-114.

54. Ullah, M. S. Islam, M. S., Islam, M. A., \& Haque, T. (2008). Effects of organic manure and chemical fertilizers on the yield of brinjal and soil properties. Journal Banladesh Agricultural University. 6(2): 271-276.

55. Bayu, W. N., Rethman, F. G., Hammes, P. S., \& Alemu, G. (2006). Effects of farm-yard manure and inorganic fertilizers on sorghum growth, yield and Nitrogen use in a semi-arid of Ethiopia. Journal Plant Nutrition; 29(2):391-307.

56. Kawthar, A. E., Rabie, H., Mana-Hasnaa, H. H., Gouda, A. H., \& Shahat, I. M. (2005). Influence of Compost and Rock Amendments on Growth and Active Ingredients of Safflower (Carthamus tinctorius L.). Australia Journal Basic and Applied Science 4(7):1626-1631.

57. Sharief, A. E. M., El-Kalla, S. E., Salama, A. M., \& Mostafa, E. I. S. (2010). Influence of organic and inorganic fertilization on the productivity of some soybean cultivars. Crop Environ, 1(1), 6-12. 